استخدام أنشطة STEM وفق الصفوف المقلوبة في العلوم لتنمية مهارات التفكير الأساسية والقيم العلمية لتلاميذ المرحلة الإعدادية العومية

* إعداد:د/ شيماء عبد السلام عبد السلام سليم

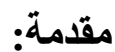

يعيش العالم في الفترة الأخيرة ثورة علمية وتكنولوجية كبيرة، كان لها تأثير اً

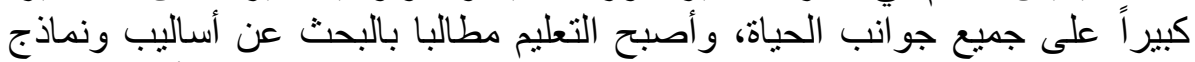

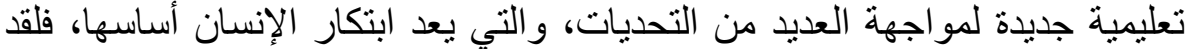

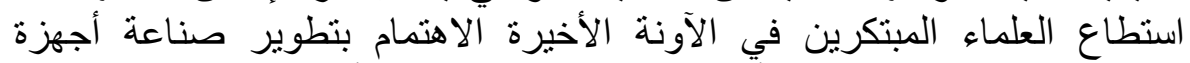

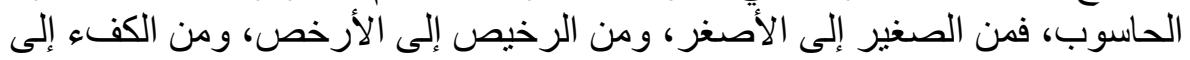

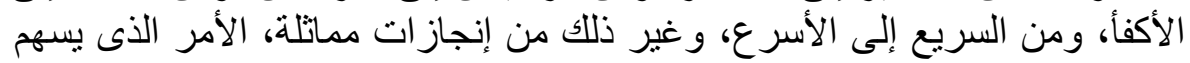

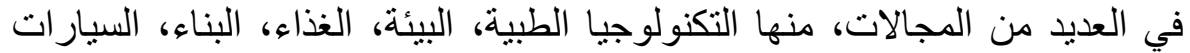

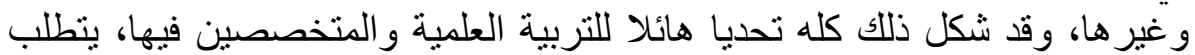

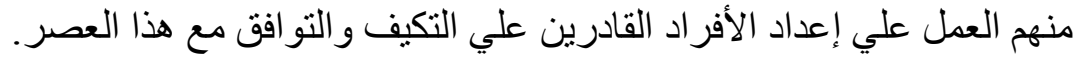

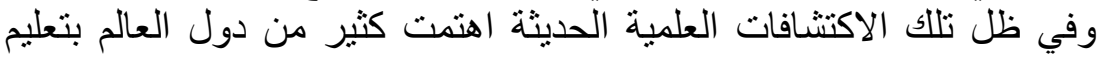

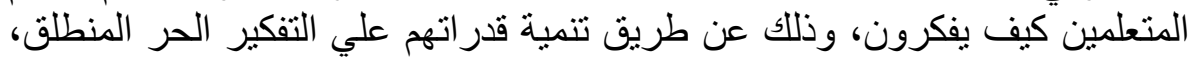

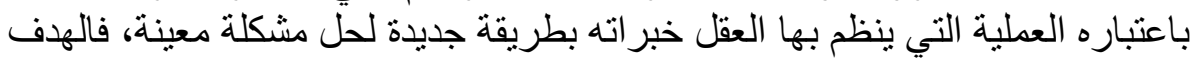

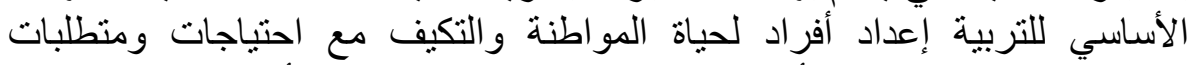

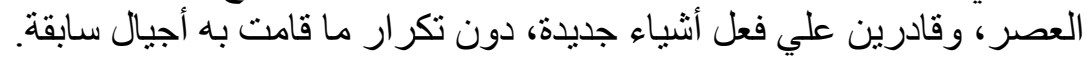

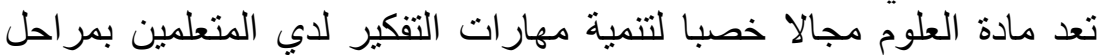

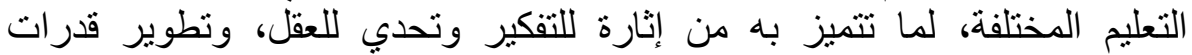

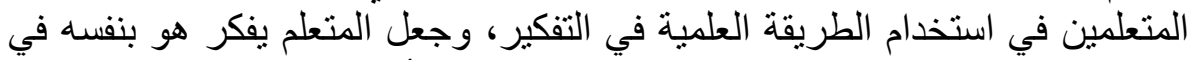

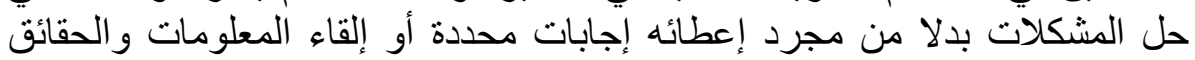

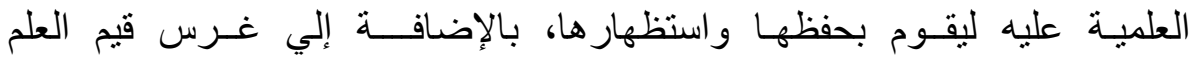

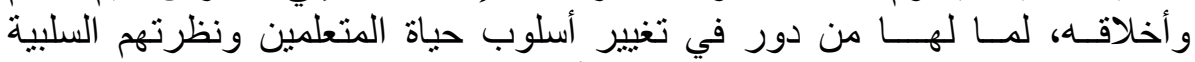

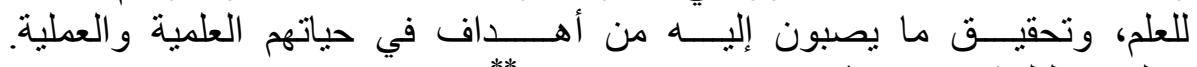

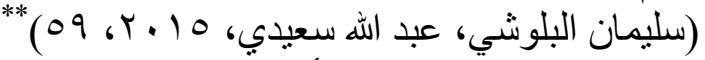

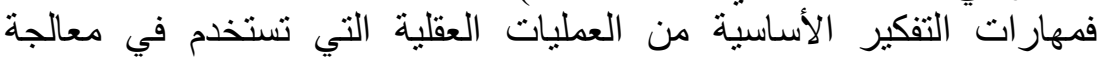

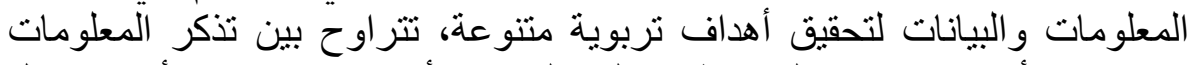

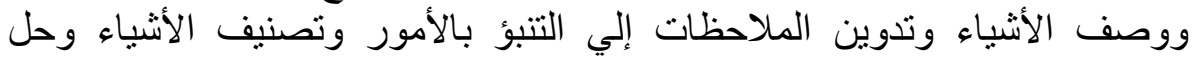
المشكلات والوصول إلي الاستتناجات، كما يمكن إكسابها للمتعلمين من خلادل إيجاد

* أستاذ مساعد المناهج وطرق تدريس العلوم ـ كلية التربية - جامعة دمياط.

" " بسير التوثيق في هذه الدر اسة علي النحو التالي: ( اسم المؤلف، سنة النشر، رقم الصفحة)

المجلة المصرية للتربية العلمية 
البيئة التعليمية التي تستثير التفكير وتساعد علي تتمية مهاراته، واستثمار ها في مو اقف جديدة ترتبط بحياتهم اليومية. (Harlen,2015,35)

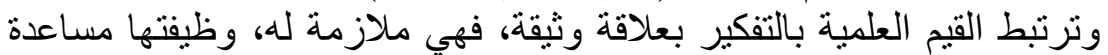

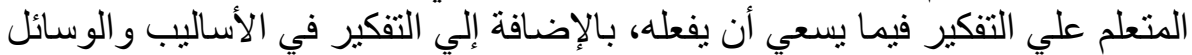
التي يختار ها في الموقف المشكل، وبالتالي يمكن النظر إلي القيم كدعامة لتفكير الفيل الفرد.

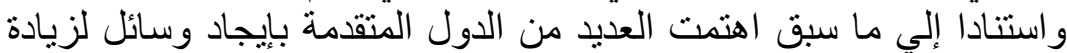

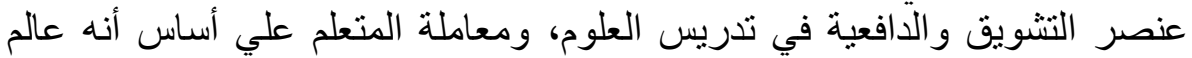

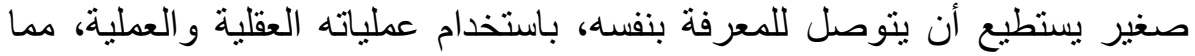

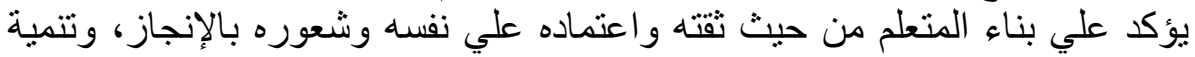

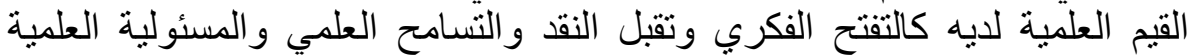

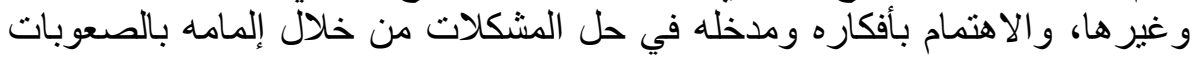

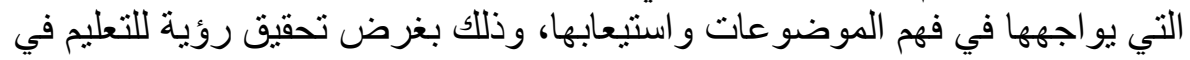
مجال العلوم و الّهنسة؛ ليتمكن المتعلمون - و وعلى مدى سنوات التهات عديدة من الدراسة بشكل فعال من الممارسات العلمية و الهندسية، وتطبية وليقيق المفاهيم الثناملة و المتداخلة،

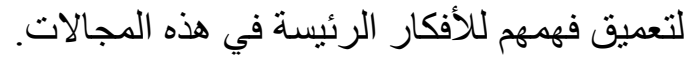

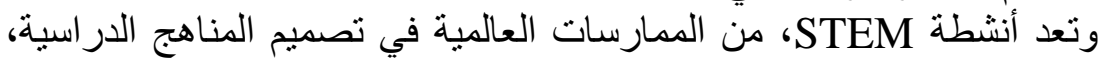

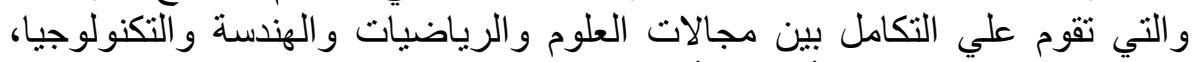

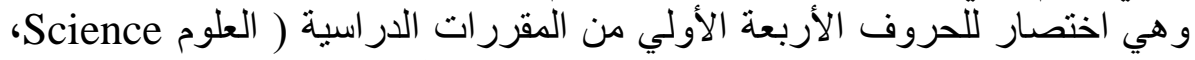

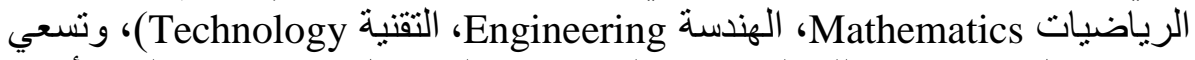

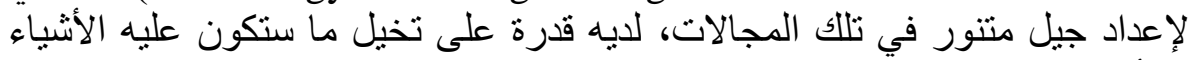

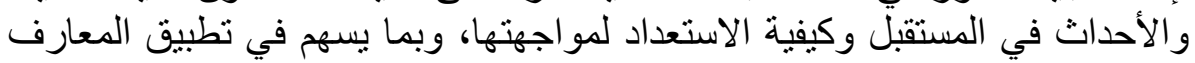

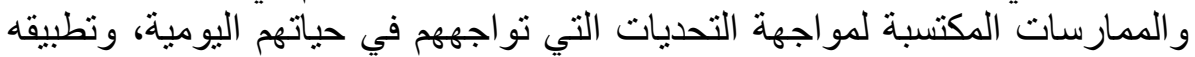

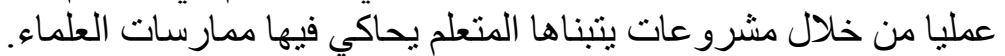
وتعتمد أنشطة STEM بالمرحلة الإعدادية علي تجهيز بيئة تعليمية مناسبة

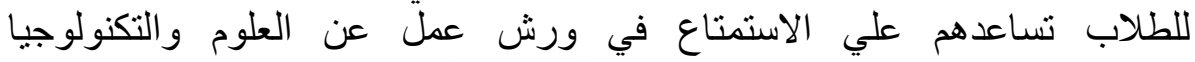

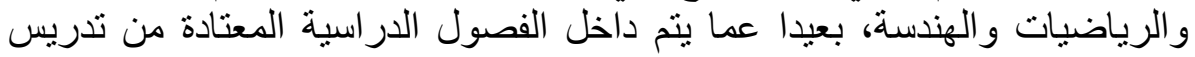

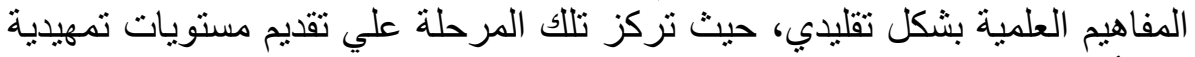

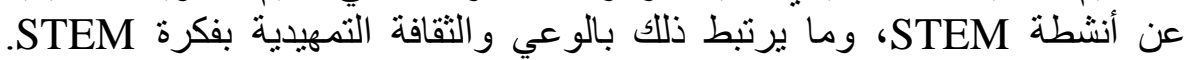

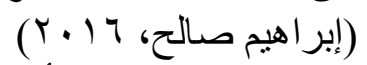

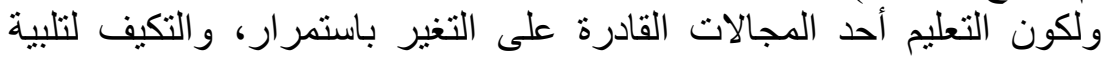

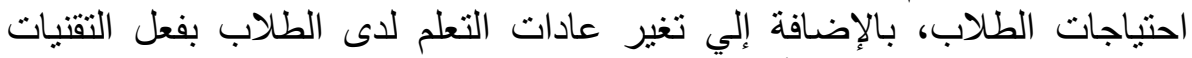

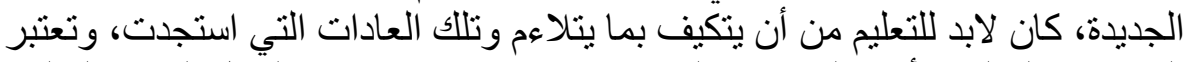

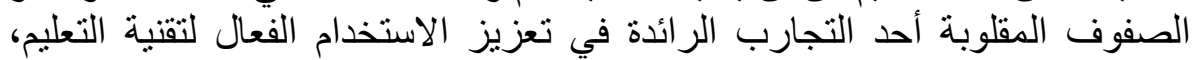

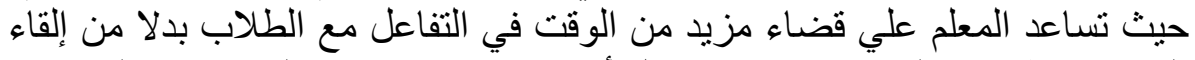

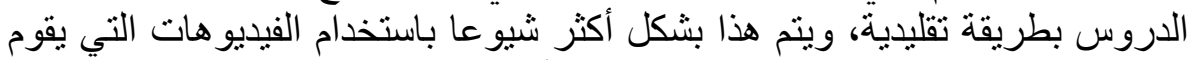

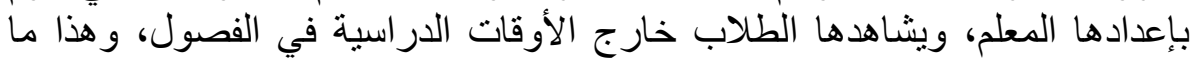




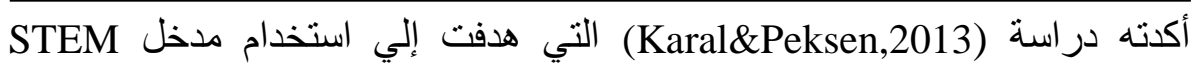

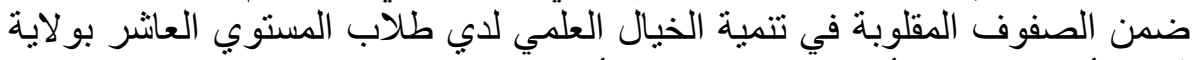

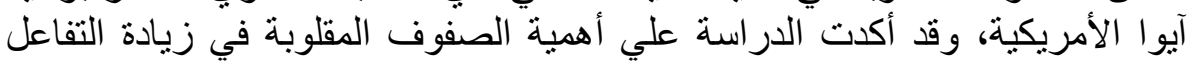
والاتصال بين الطلاب والمعلمين، بالإضافة إلي خلق بيئة تعلمية تحفز الهية مشاركة الطلاب في تحمل مسئولية تعلمهر.

\section{الاحساس بالمشكلة:}

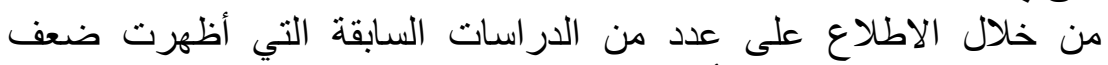

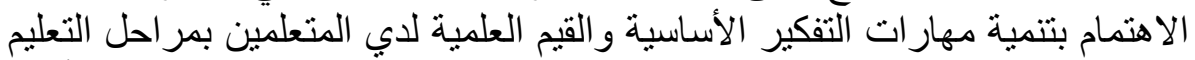

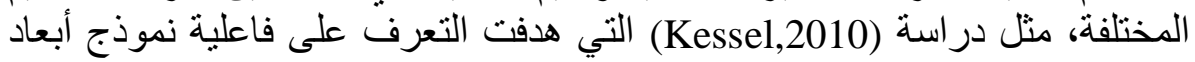

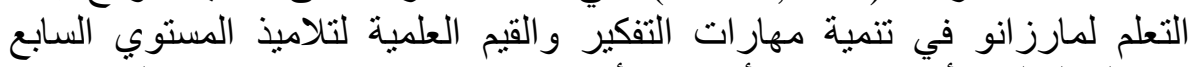

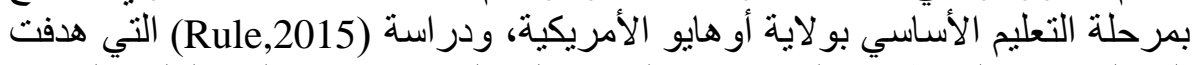
إلي التعرف علي طبيعة العلاقة بين القدرة علي الاعريكة التفكير ودتمية القيم العلمية لتلاميذ المستوي الخامس بمرحلة التعليم الأساسي. ومن خلال الاطلاع علي تقرير الدراسة الدانية الدانية للعلوم التي أعدها برنامج الأمم المتحدة الإنمائي (UNDP)

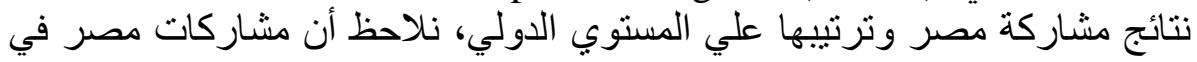

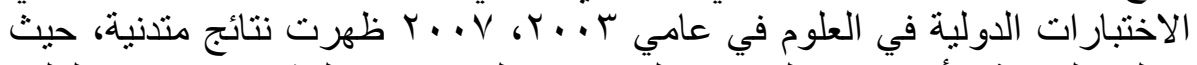

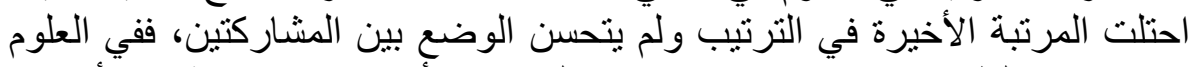

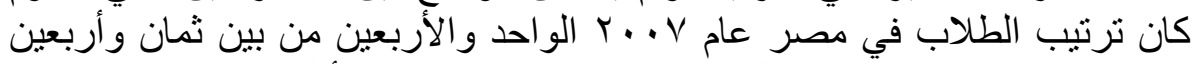

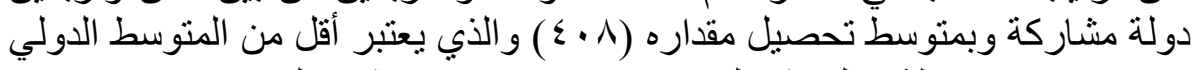

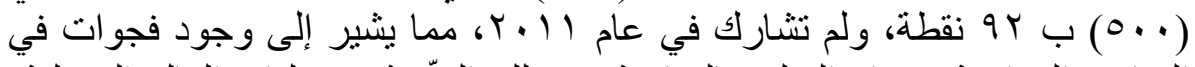

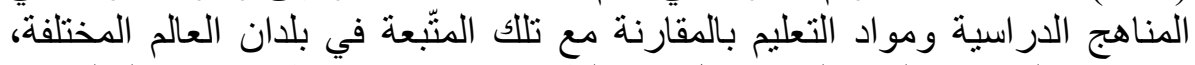

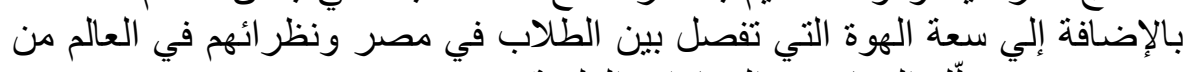

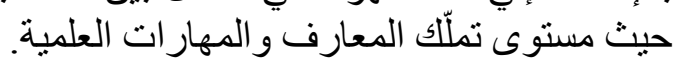

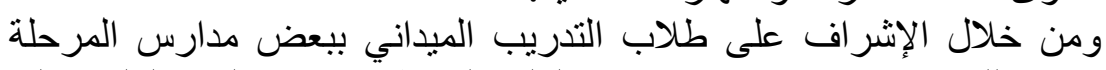

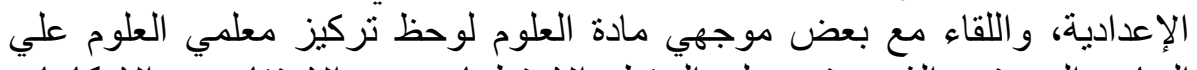

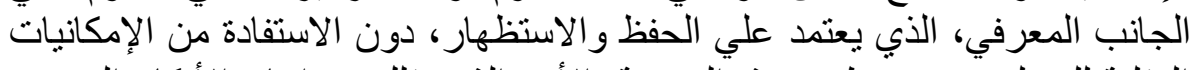

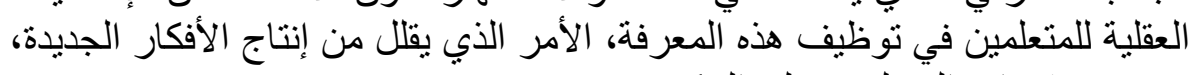
ويحد من قدرات المتعلمين علي التفكير.

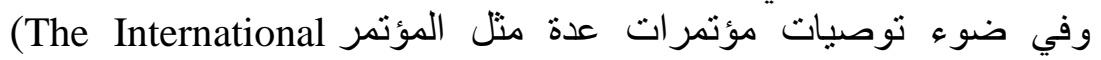

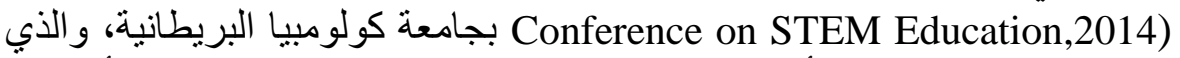
أوصي بضرورة تضمين أنشطة STEM بمناهج العلوم بمر احل التعليم الأساسي، ولئيل

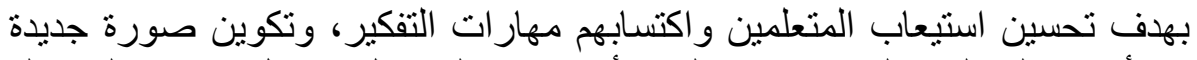

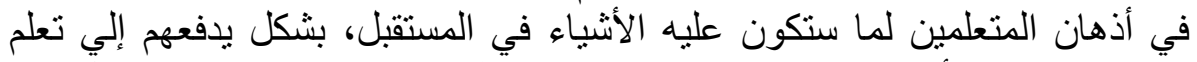

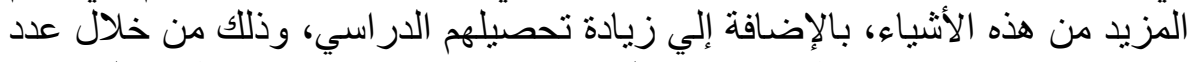

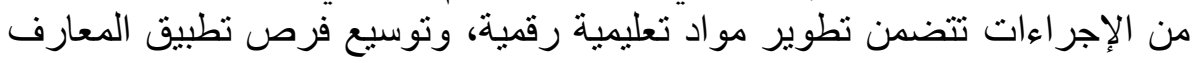


و المهار ات العلمية والرياضية، وبناء الاتجاهات الإيجابية من خلال المعارض و المسابقات التعليمية.

من كل ما سبق تبين للباحثة علي الرغم من أهمية إكساب تلاميذ المرحلة

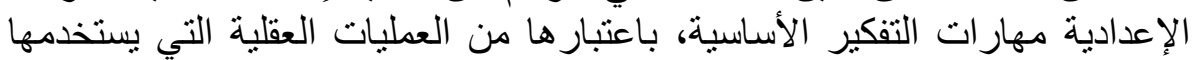

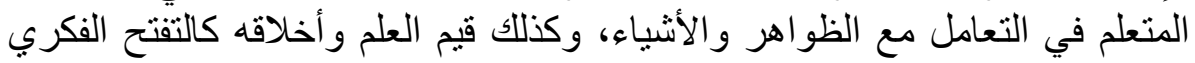

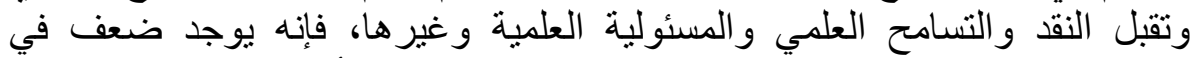

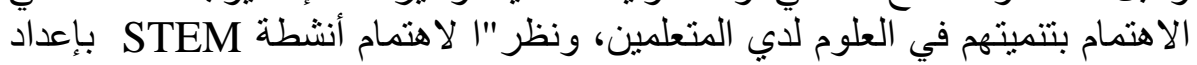

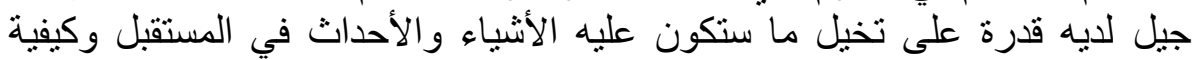

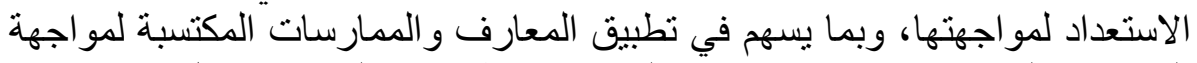

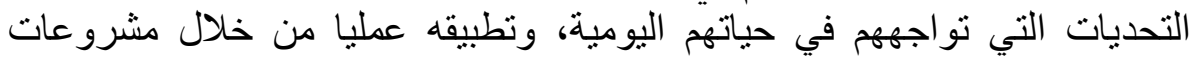

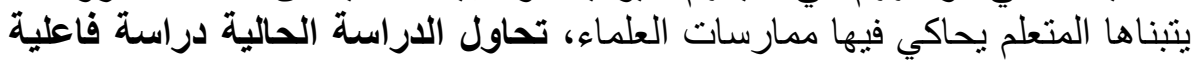
استخدام أنشطة STEM وفق الصفوف المقلوبة في العلوم لتنمية مهارات التفكير الأسساسية والقيم العلمية لتلاميذ المرحلة المبلة الإعدادية.

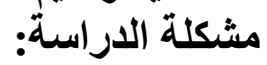

تكمن مشكلة الدراسة الحالية في ضعة ضلف الاهتمام بتنمبة مهارات التفكير

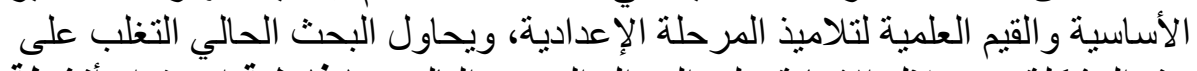

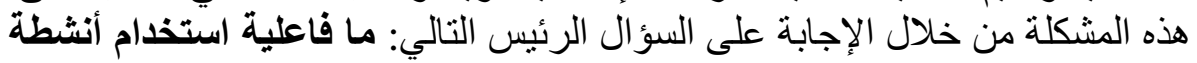

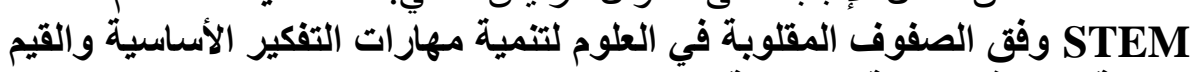

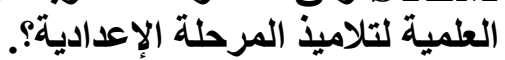
ويتفرع من هذا السؤال الأسئلة الفرعية الأبلة التالية:

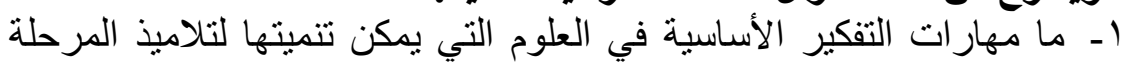

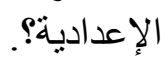

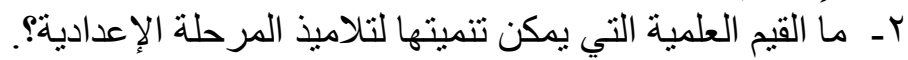

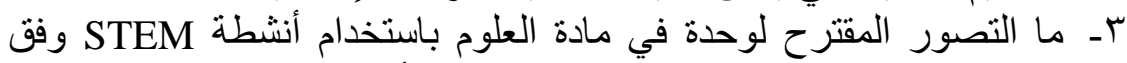
الصفوف المقلوبة في تتمية مهار ات التفكير الأساسية و القيم العلمية لتلاميذ

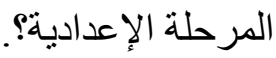
عـ - ما فاعلية استخدام أنشطة STEM وفق الصفة الصفوف المقلوبة في تتمية مهار ات

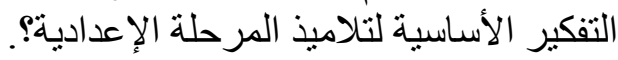

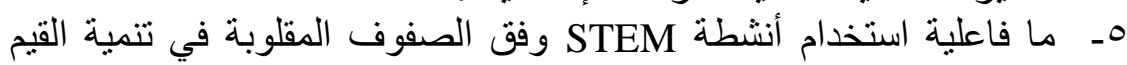
العلمية لتلاميذ المرحلة الإعدادية التهبه

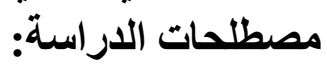

Science Technology Engineering Mathematics (STEM) أنشطة Activities لقد تعددت التعريفات التي تناولت مفهوم أنشطة STEM، نذكر منها تعريف

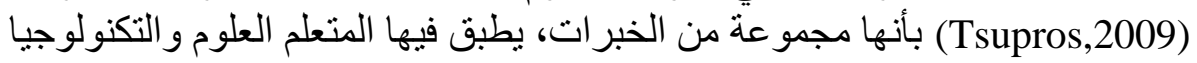
و التصميم الهندسي و الرياضيات، باستخدام مجمو عة من الطرق العملية الاستقصائية 
المتمركزة حول المتعلم، والمعتمدة علي مدخل حل المشكلات في بنائها، وتعرفها

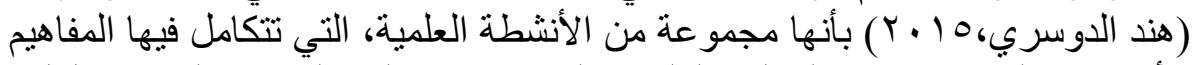

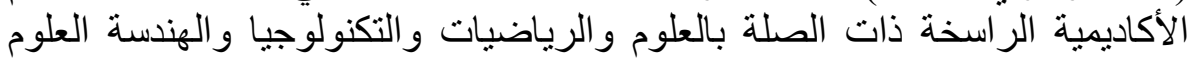

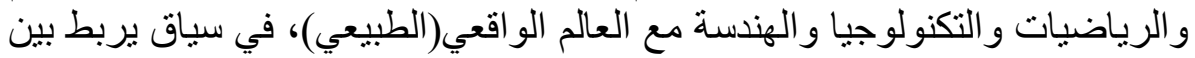

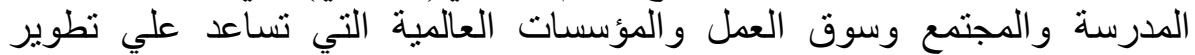
ويمكن تعريف أنشطة STEM إجرائيا على أنها مجموعة من الخبرات

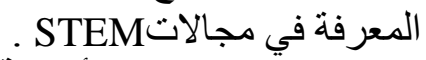
و الممارسات العملية التطبيقية، والممارسات التكنولوجيات التولية الرقمية و الكمبيوترية،

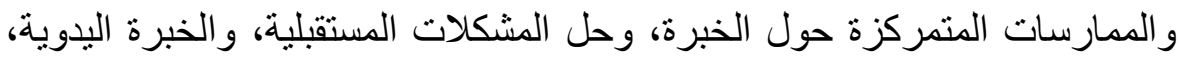

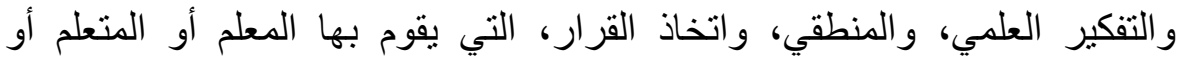

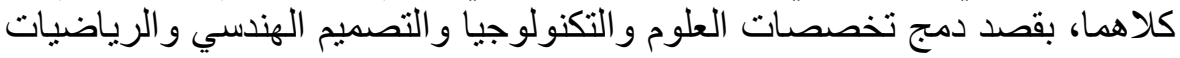

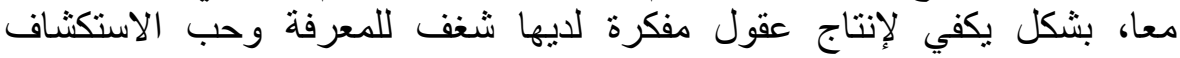

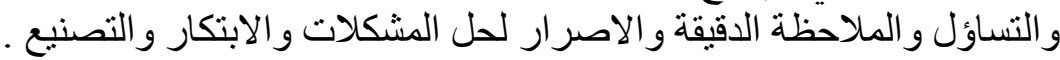

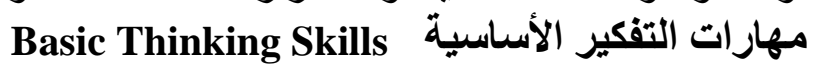

لقد تعددت التعريفات التي تتاولت مفهوم مهارات التفكير الأساسية، نذكر منها

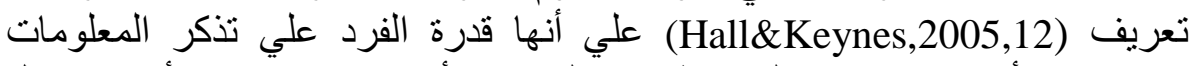

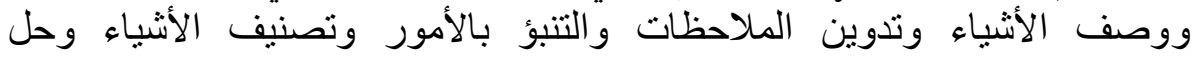
المشكلات والوصول إلي الاستتناجات، واستثمار ها في مواقف ولأن جديدة ترتبط بحياته

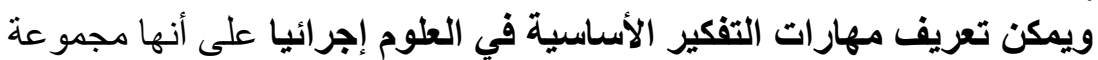
اليومية.

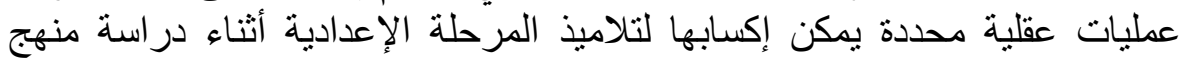

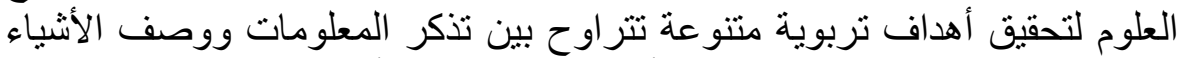

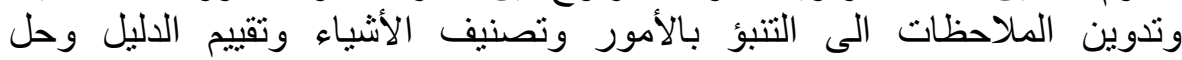

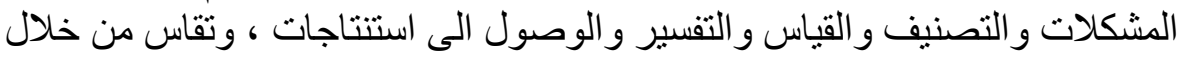

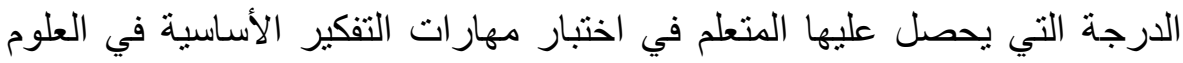

\section{Scientific Values القيم العلمية لفية}

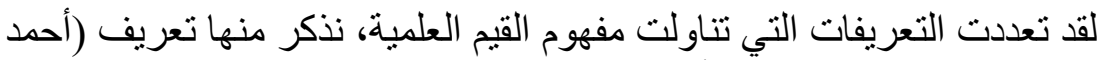

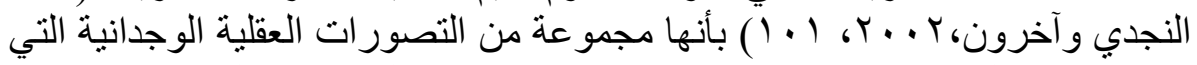

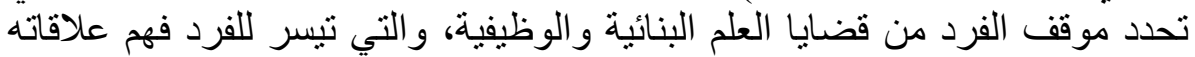

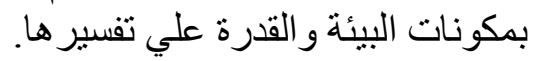
ويمكن تعريف القيم العلمية إجرائيا على أنها مجموعة الاتجاتجاهيات التهات التي تتكون

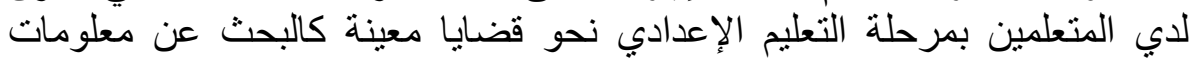

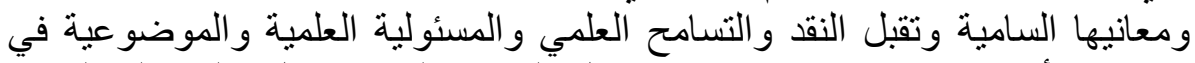

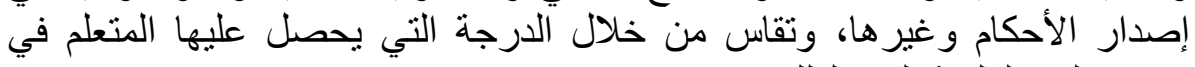
مقياس القيم العلمية المعد لذلك. 


\section{Flipped Classroom الصف المقلوب}

لقد تعددت التعريفات التي تناولت مفهوم الصف المقلوب، نذكر منها تعريف

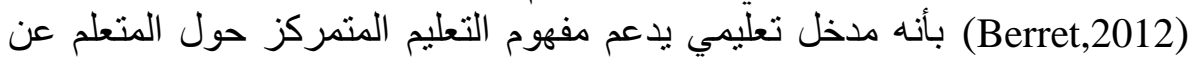

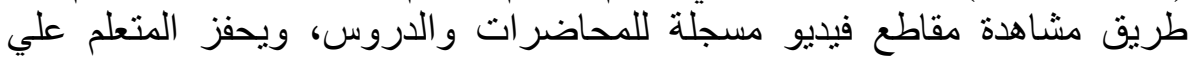

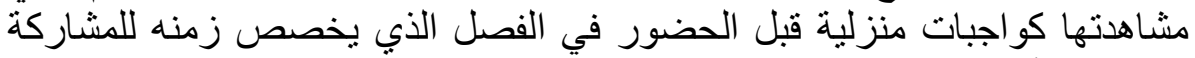
بفعالية في أساليب حل المشكاتلات بشكل فئل جماعي. ويمكن تعريف الصف المقلوب إجرائياً علي أنه مدخل تعليمي يوظف التف التعلم

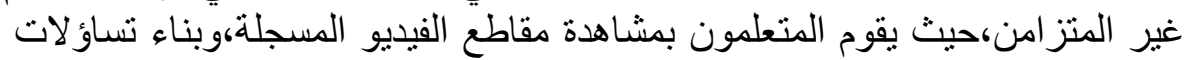

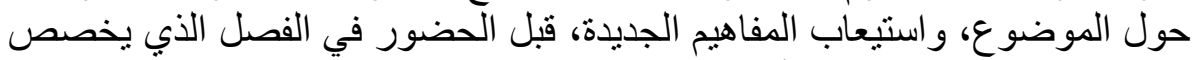

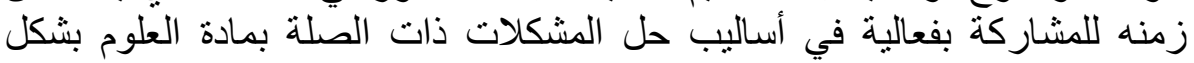

ويمكن تعريف أنشطة STEM وفق الصفوف المقلوبة إجرائيا علي أنها

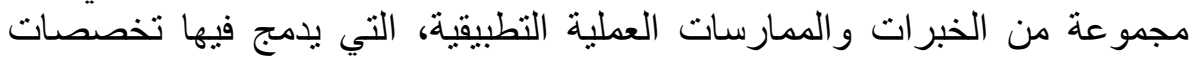
العلوم و التكنولوجيا والتصميم الهندسي و الرياضيات معا، ويقوم المتعلمون بمشاهدتها من خلال مقاطع فيديو مسجلة كواجبات منزلية، بهدف بناء تساؤلات التأ حول

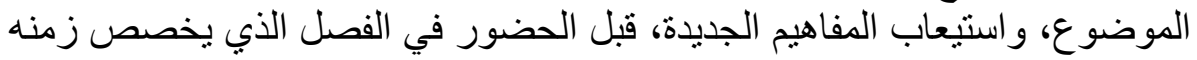

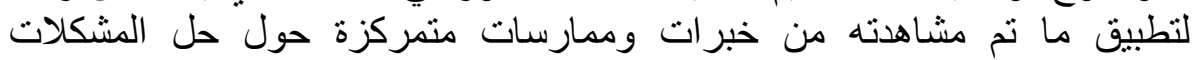

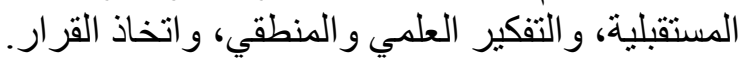

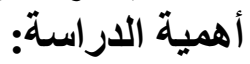

ا - إلقاء الضوء الراءة على الوضع الراهن لمنهج علوم المرحلة الإعدادية، ومدى دمى

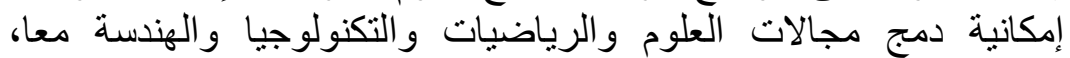
وبصورة وظيفية فعالة تكسب التلاميذ القاعدة المعرفية العلمية، و المهار ات اتليات

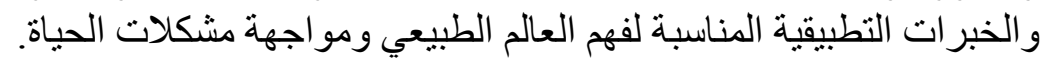

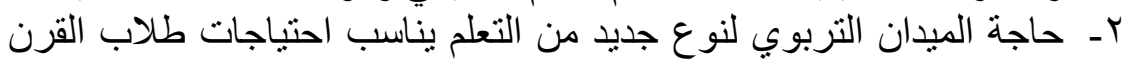

الحادي و العشرين وتوجهاتهج.

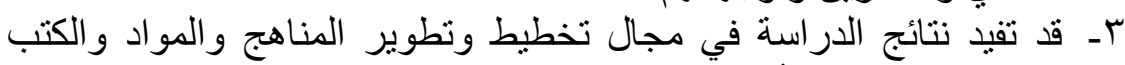

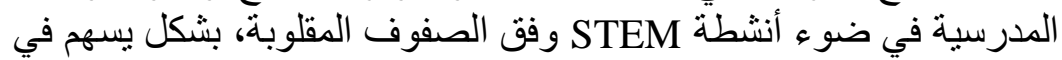

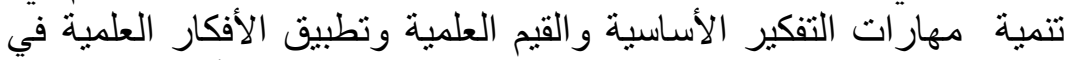

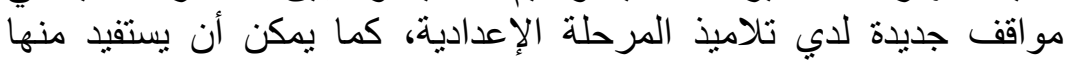
مخططي ومطوري بر امج الإعداد لمعلمي العلوم بكليات التربية.

أهداف الدراسة: مخطي

تهدف هذه الدراسة إلي تدريس العلوم باستخدام أنشطة STEM وفق الصن الصفوف

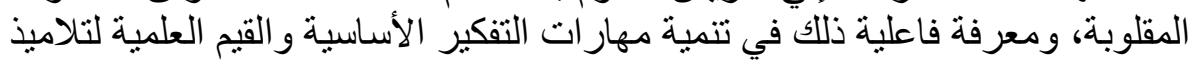
المرحلة الإعدادية. 
حدود الاراسة: تقتصر الدر اسة الحالية على ما يلى:

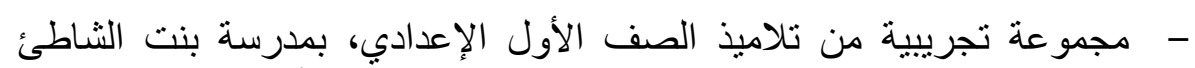

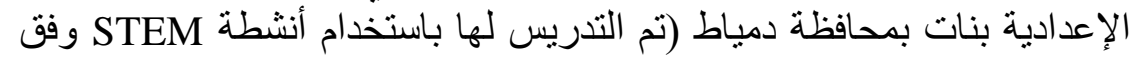

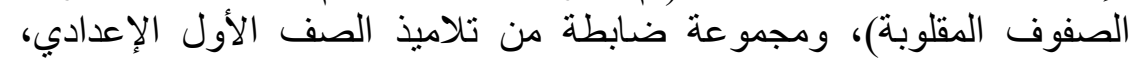

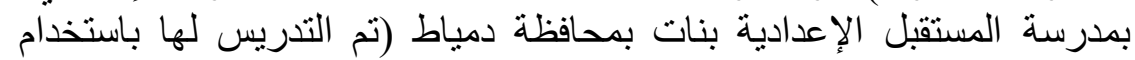
أنشطة STEM وفق الطريقة المعتادة). - - قياس مهار - ق فياس القيم العلمية لتلاميذ الصف الصفي الأول الإعدادي.

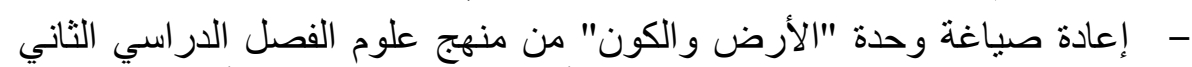

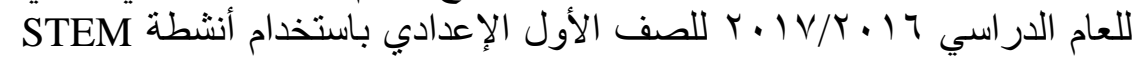

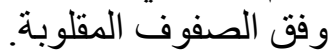
أدوات ومواد الدراسة: للتحقق من صحة فروضة الألة الدراسة والإجابة على أسئلتها، تم

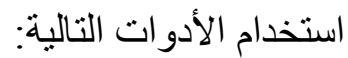
- - اختبار مهار ات التفكير الأساسية في العلوم، من إعداد الباحثة. - - مقياس القيم العلمية، من إعداد الباحثة.

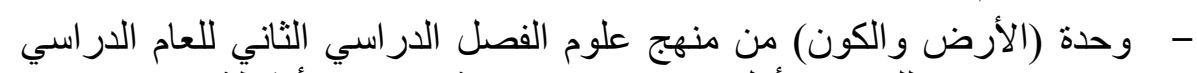

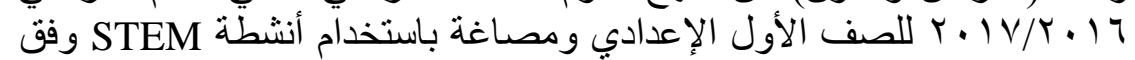

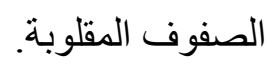
- - دليل المعلم الخاص بوحدة (الأرض و الكون)، ومصاغ باستخدام أنشطة STEM وفق الصفوف المقلوبة. منهج الار اسة وإجراءواتهاته:

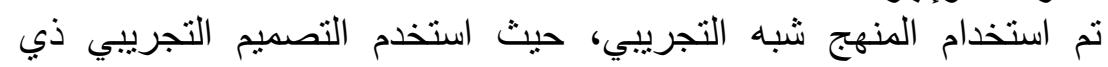

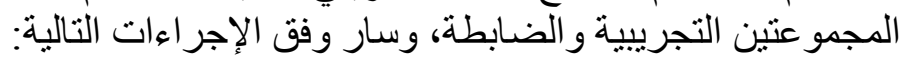

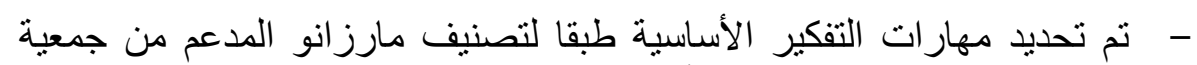

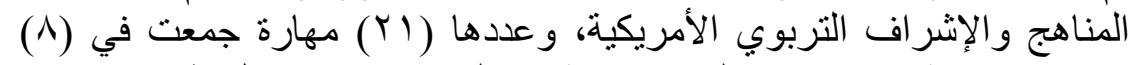

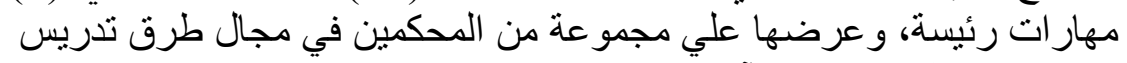

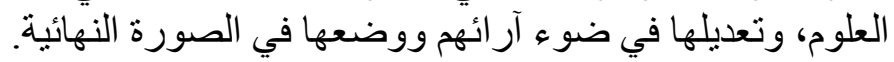

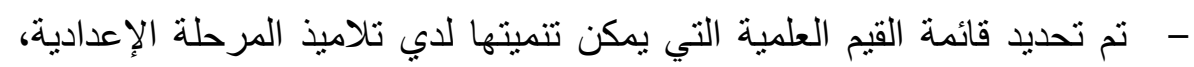

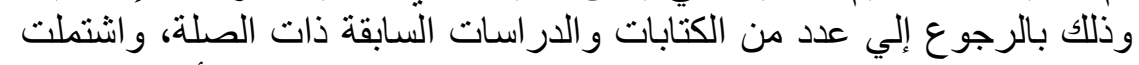

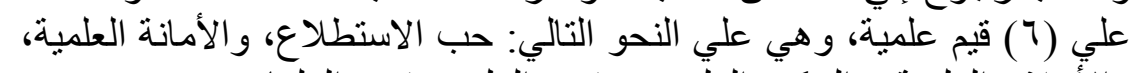

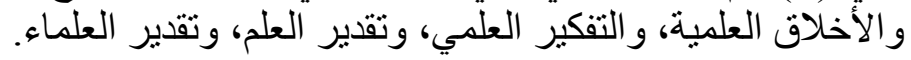

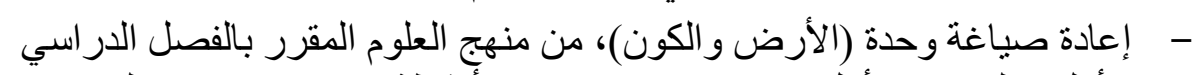

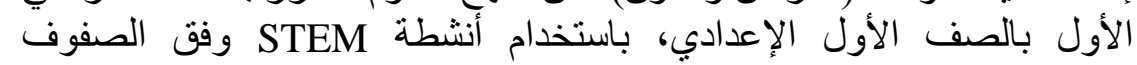

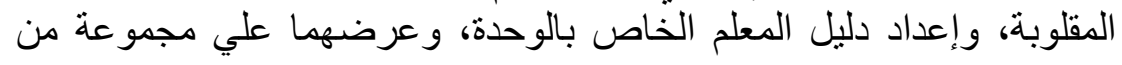


المحكمين في مجال طرق تدريس العلوم، وتعديلهما في ضوء آرائهم ووضعهما في الصورة النهائية.

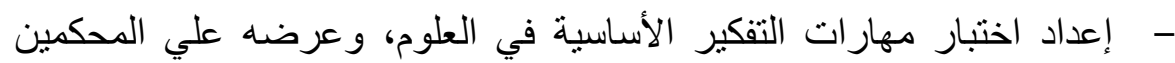
وتعديله في ضوء آر ائهم لإجر اء عمليات ضبط الاختبار علميا.

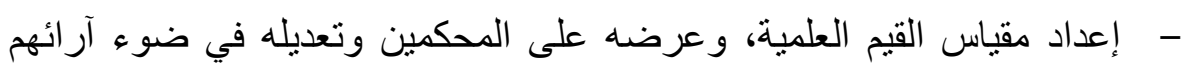
لإجر اء عمليات ضبط المقياس علميا.

- - تطبيق اختبار مهارات التفكير الأساسية في العلوم، ومقياس القيم العلمية قبليا على مجموعتي الدر اسة.

- تدريس الوحدة، بالاستعانة بدليل المعلم المعد لتلاميذ المجمو عة التجريبية، بينما

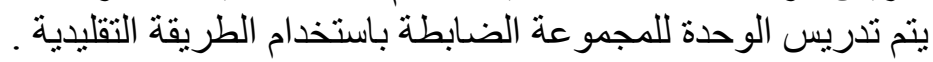

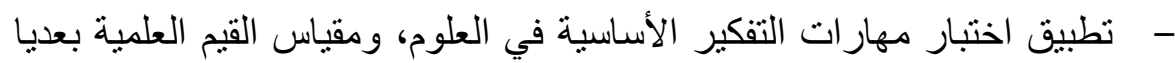
على مجمو عتي الدر اسة. - - إجر اء المعالجة الاحصائية للنتائج وتفسير ها. الإطار النظري والدراس استات السابقة: - - توصيات الدر اسة ومقترحاتها.

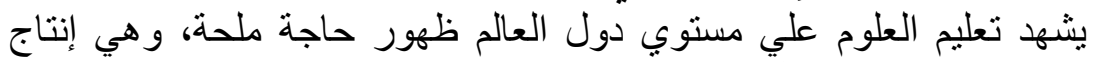

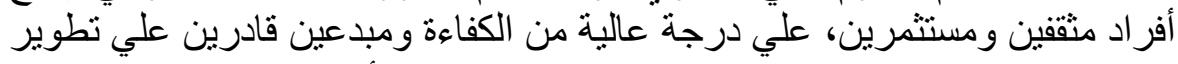

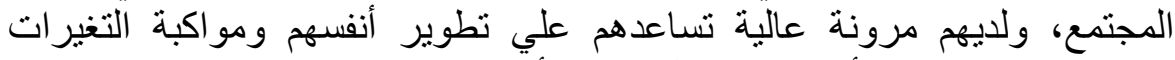

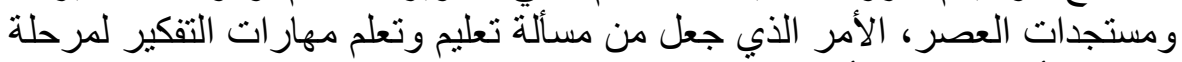

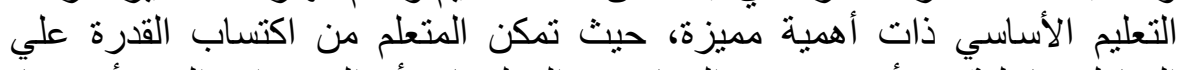

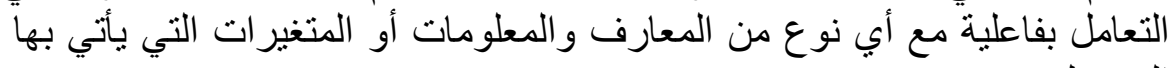

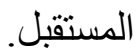

وانطلاقا من أن تتمية مهارات التفكير أحد الأهداف التربوية التي تسعي

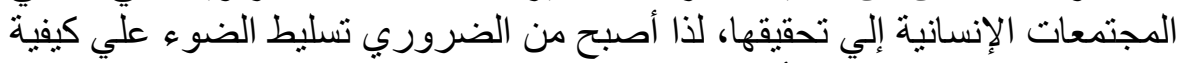

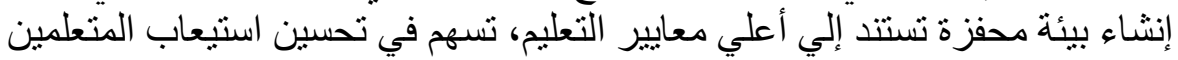

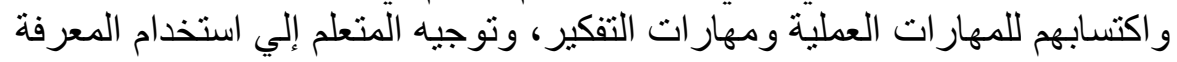

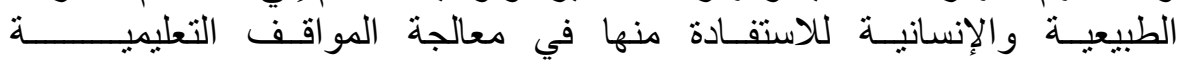

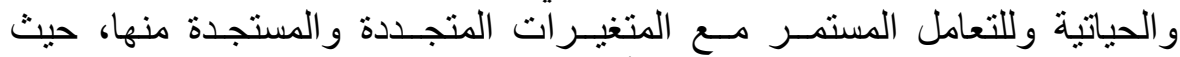

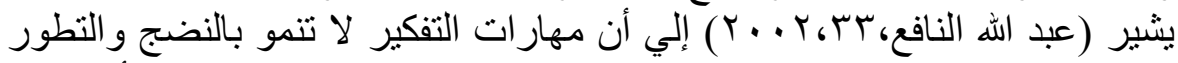

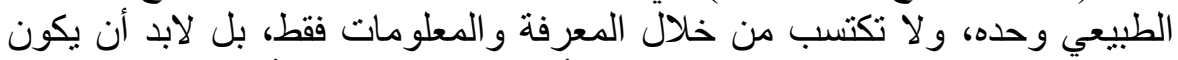

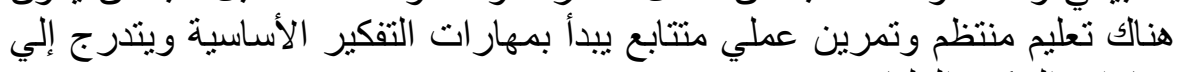

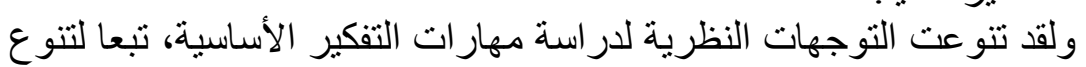
مهار ات التفكير العليا.

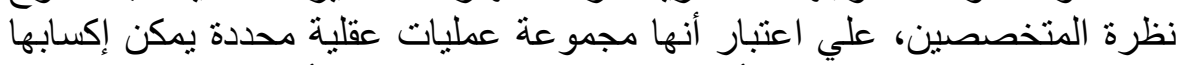

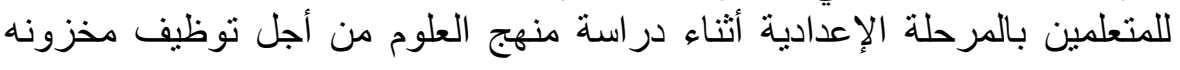




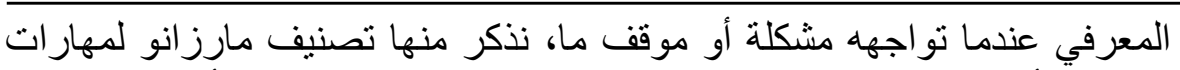

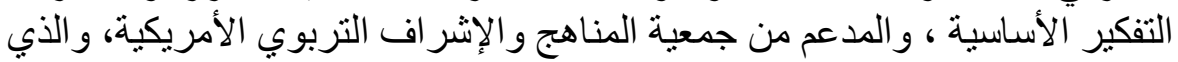

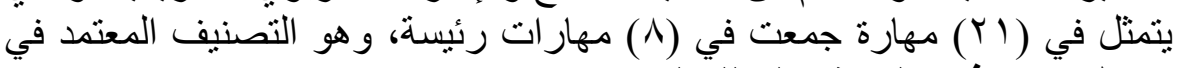
هذا البحث، وفيما يلي تفصيل تلكت المهارات:

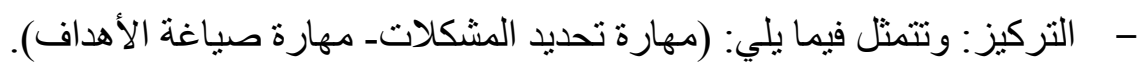

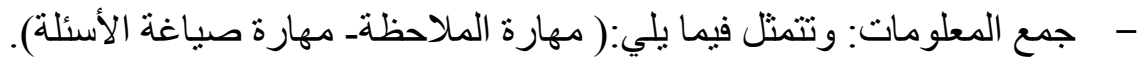

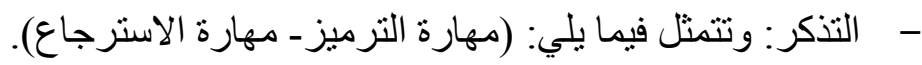
- تنظيم المعلومات: وتتمثل فيما يلي: (مهارة المقارنة ـ مهارة التصنيفــ مهارة الترتيب- مهارة التمثيل).

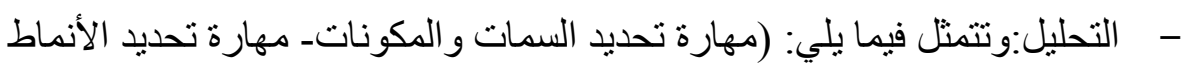

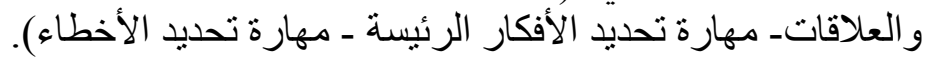

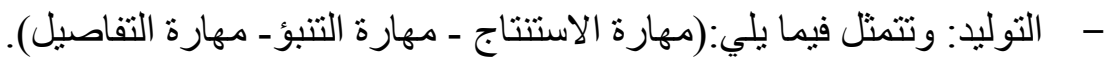
- التكامل: وتتمثل فيما يلي: (مهارة التلخيص- مهارة إعادة البناء).

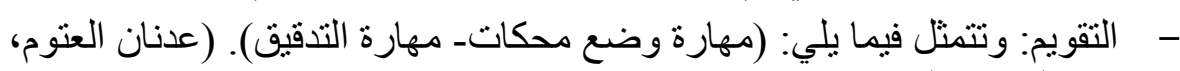

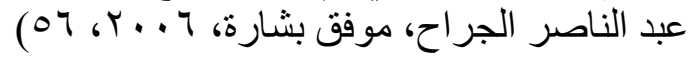

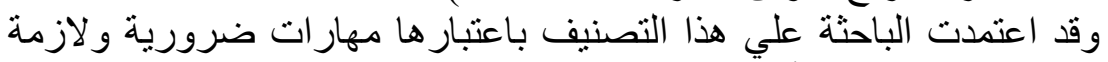

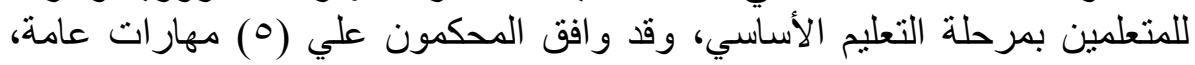

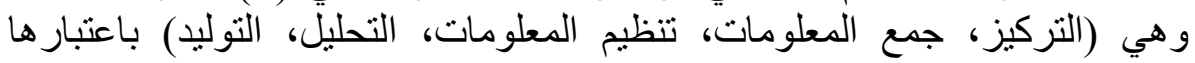

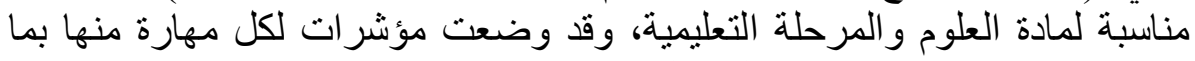
يتتاسب مع مادة العلوم في هذه المرانة المرحلة.

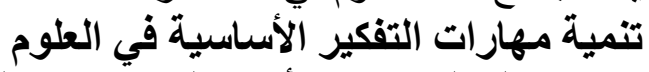

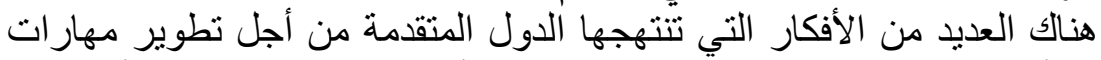

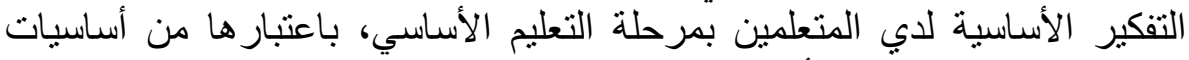

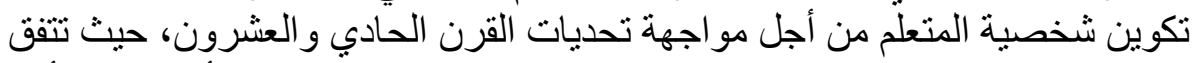

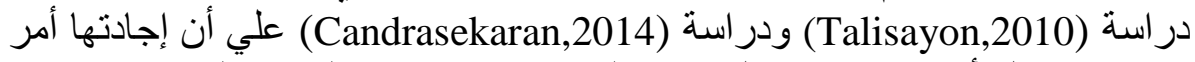
ضروري قبل أن يصبح الانتقال ممكنا لمواجهة مستويات التفكير المركب بصورة المانها فعالة، ومن أمثلة تلثك الأساليب:

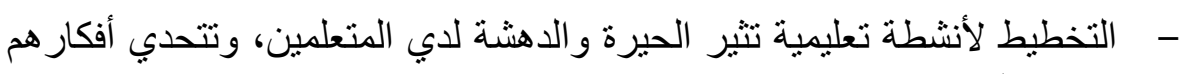
وتصور اتهم.

- - التخطيط لأنشطة تعليمية تتطلب مواد قرائية إضافية، و إصدار أحكاما وحلو لا بديلة.

- إعداد الدروس في العلوم علي هيئة مشكلات كبري يتفرع منها مشكلات صغرب. - - التخطيط لأنشطة تعليمية تسمح للمتعلمين بالعمل الجماعي وتبادل الأفكار. 
- عزيز إجابات المتعلمين التي تعكس مرونة في التقكير.

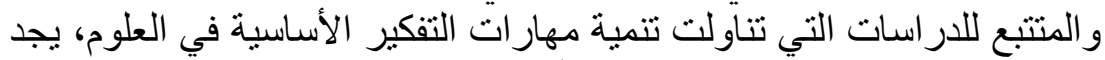

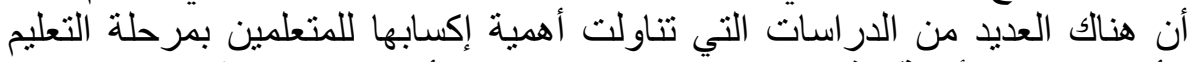

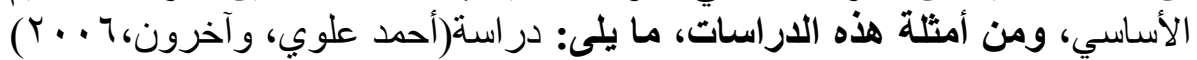

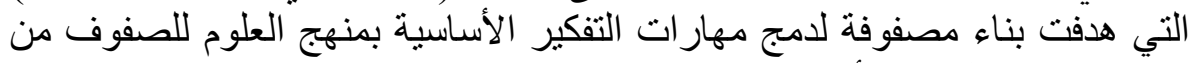

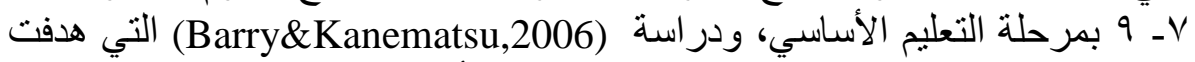
استخدام المعارض العلمية لتنمية مهار ات التفية التفكير الأساسية لدي تلاميذ مرحلة التعليم الأساسي في اليابان. وترتبط القيم العلمية بمهارات التفكير ارتباطا وثيقا، فالقيم تساعد الفرد علي

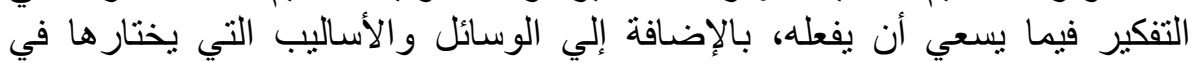

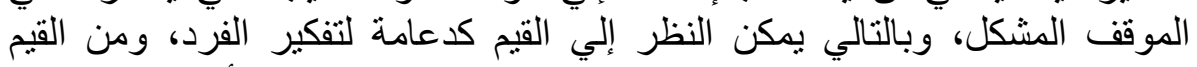

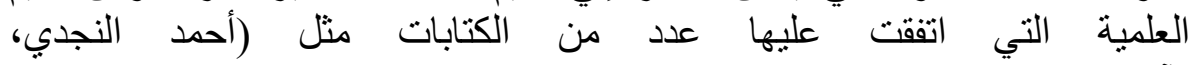

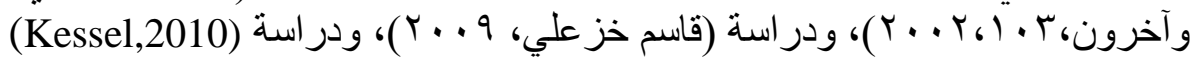

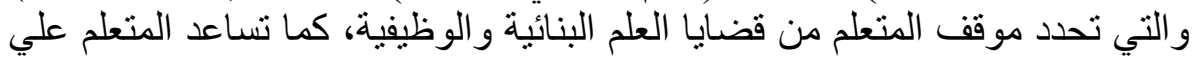

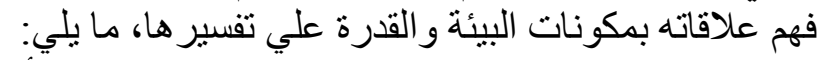

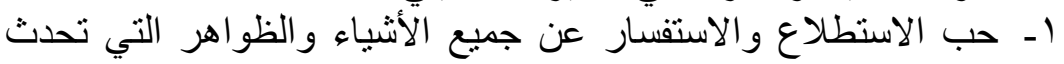

$$
\text { حولنا. }
$$

r- الأمانة العلمية.

r- بـ الأخلاق العلمية.

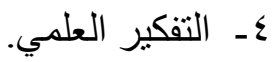

0- تقدير العله.

7- تقدير العلماء.

أساليب تنمية القيم العلمية بمرحلة التعليم الأساسي:

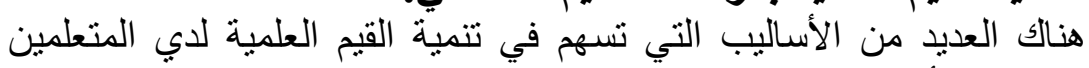

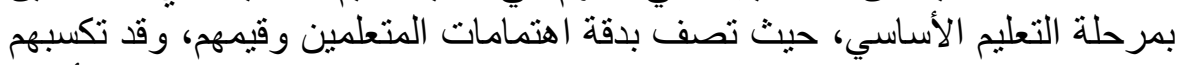

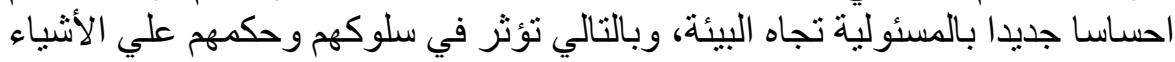

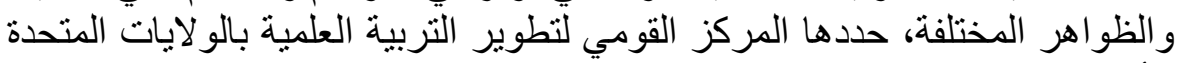

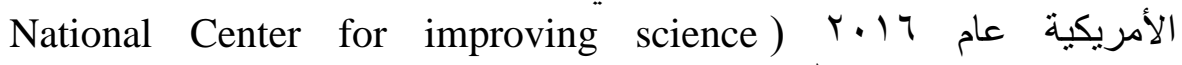
education,2016)

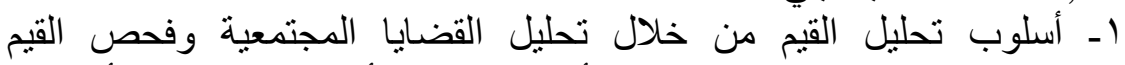

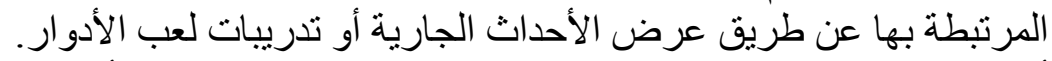

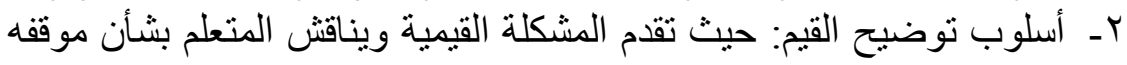

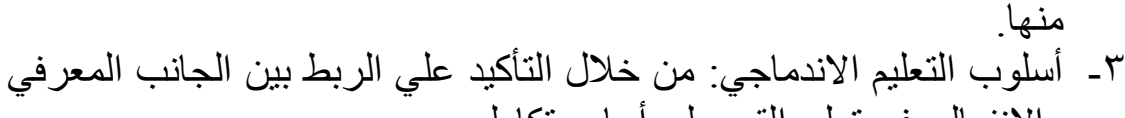
والانفعالي في تعليم القيم علي أساس تكاملي. 
ع- أسلوب تعديل السلوك: حيث يتم فيها تعديل السلوك ونتشكيله علي أساس استخدام أنماط التعزيز النطائ الخارجية.

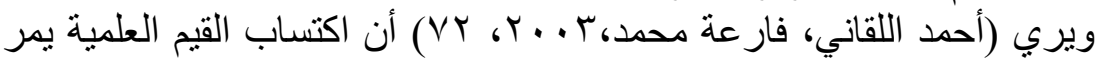

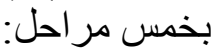
1 - - جذب انتباه المتعلم نحو القيمة.

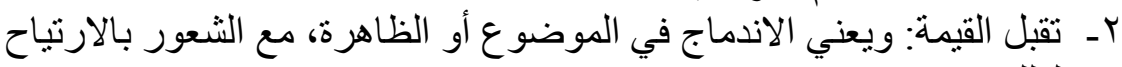
لذلك r- تفضيل القيمة: عندما يعطي المتعلم قيمة أو تقدير للأشياء أو الظواهر أو أو الوكاء

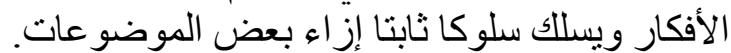

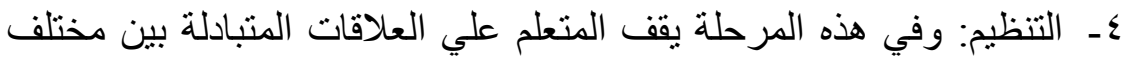

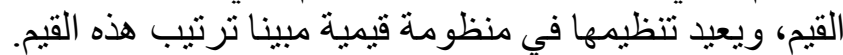

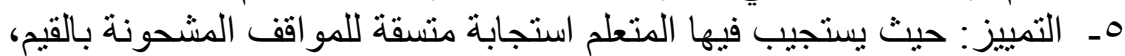

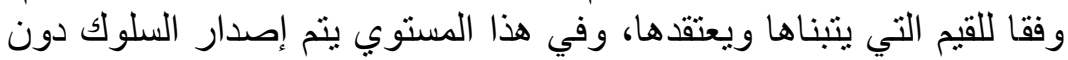

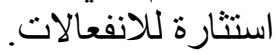

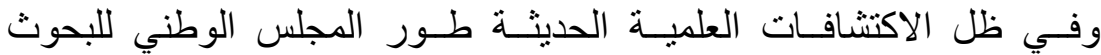

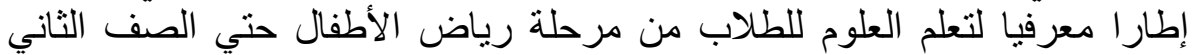
عشر K-12، وذللك من أجل تمكين المتعلمين من قدرات التعات التصميم التقني، ولتعزيز

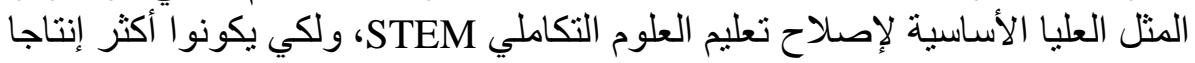
و واطلاعا في حياتهم، بالإضافة إلي استثمار المعرفة العلمية في الإلي مهارات حياتية، وتعزيز عقلية الاستفسار و التحقق والتفكير المنطقي ومهار ات التعاتئ التهاون و العمل كفريق.

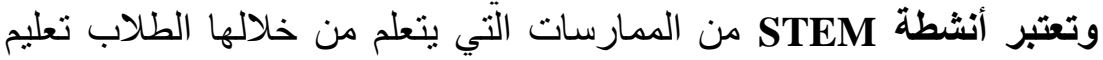

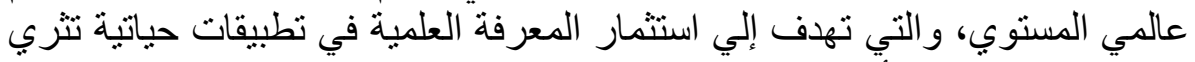

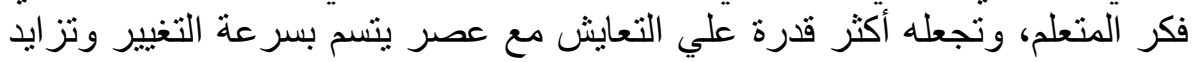

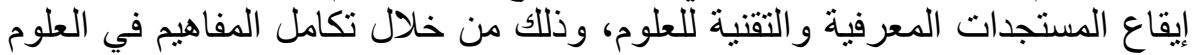
و التكنولوجيا و الهندسة والرياضيات، وذلك بحكم طبيعتها، وتتمثل مجالات STEM فيما يلي:

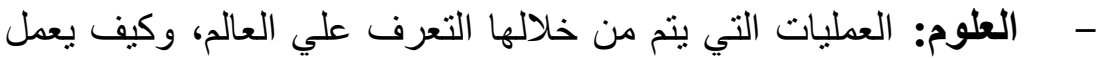

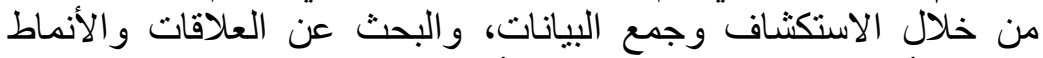
وتوليد الأفكار و التفسير ات باستخدام الأدلة.

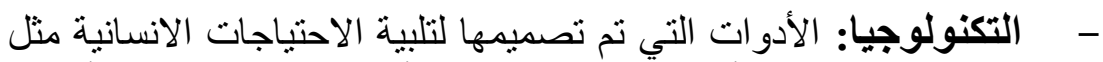

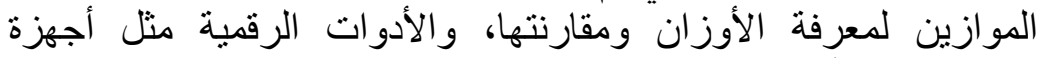

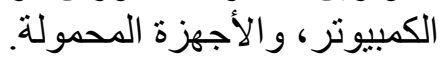

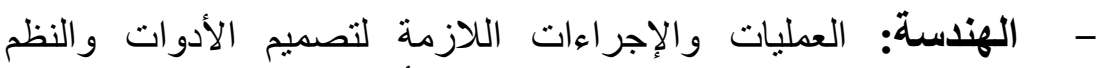
و الهياكل التي تساعد البشر وتلبي احتياجاتهم أو تحل مشاكلهم.

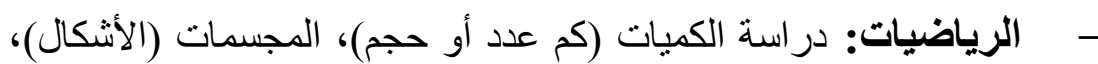
و الفضاء (الزوايا و المسافات)، و التحويلات في أوقات أولات مختلفة. 
فعلي سبيل المثال عندما يبني المتعلم البرج من مجموعة من المكعبات، فإنها

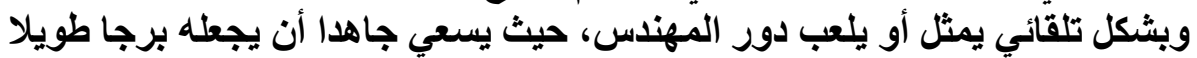

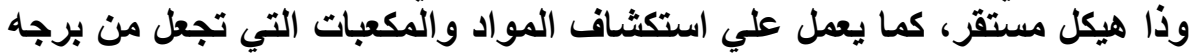

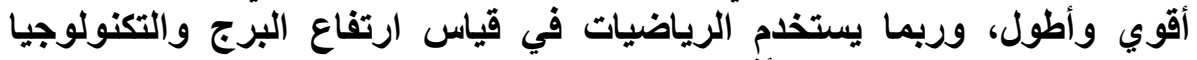
للحصول علي صور لتصاميم أفضل.

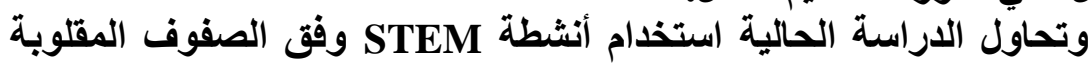

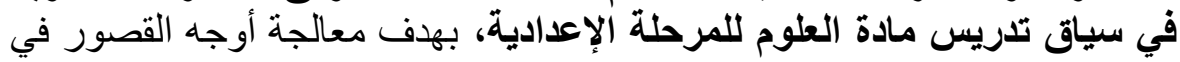

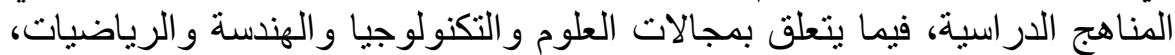

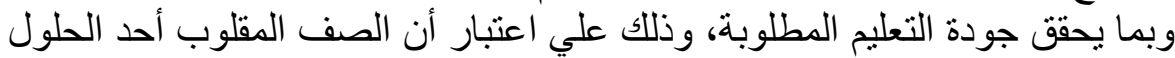

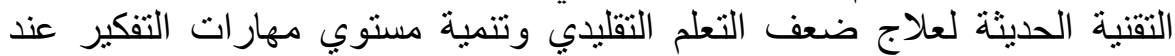

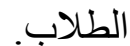

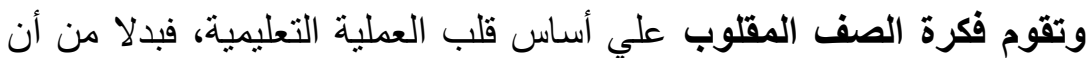

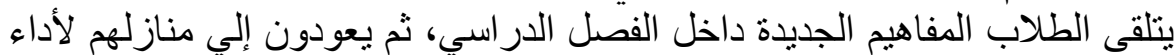

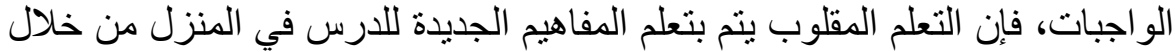

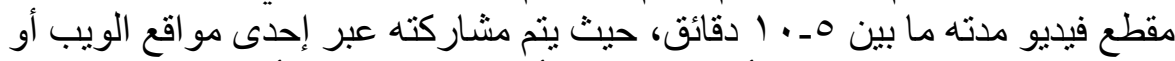

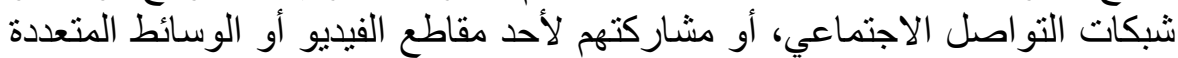

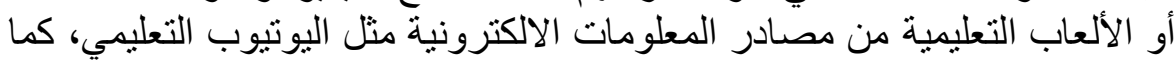

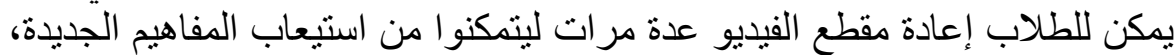

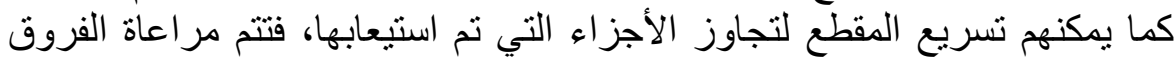

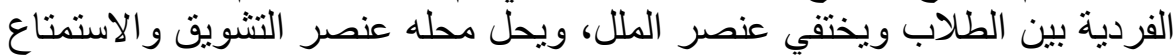

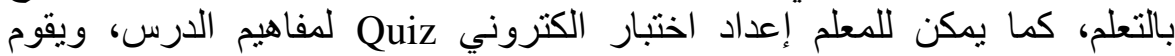

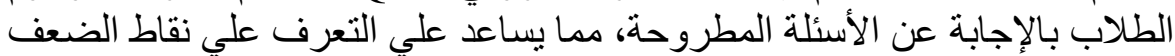

و القوة وتحديد مستوي استيعابهم. (Gaughan,2014,229)

وقد أثتتت دراسة (Bormann,2014) التي استهدفت مراجعة أكثر من

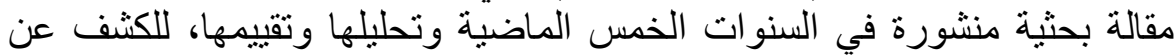

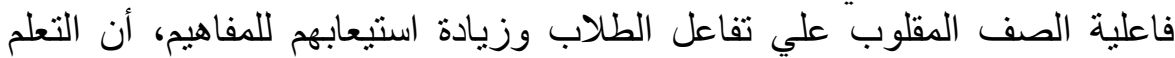

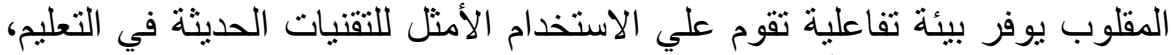

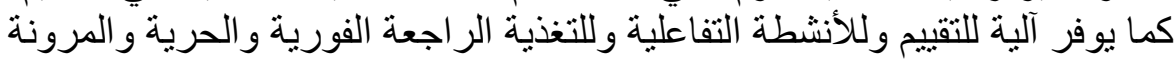

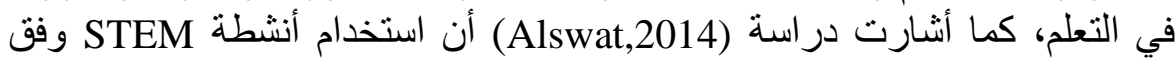
الصفوف المقلوبة يحتوي علي نوعين من الأنشطة التعليمية التعلمية: - - التعلم الفردي الموجه خارج الفصل، عن طريق مشاهدة مقاطع الفيديو المسجلة. - - التعلم التفاعلي الجماعي بين الطلاب أثناء وقت الحصة.

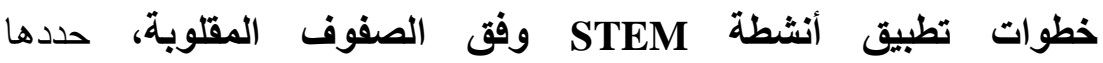
(Gaughan,2014,234) 
1- يكلف المعلم التلاميذ بتعلم المفاهيم الجديدة للارس في المنزل من خلال مقطع

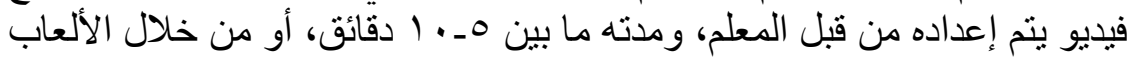

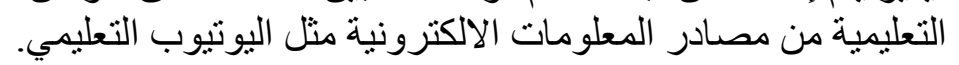

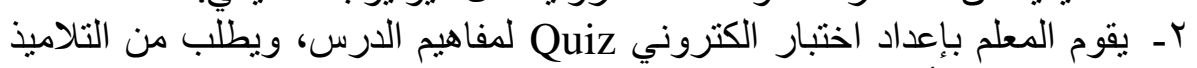

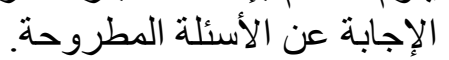

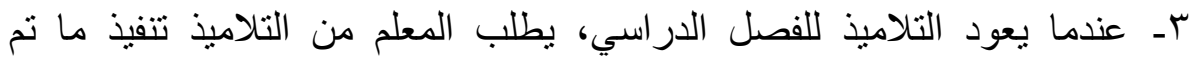

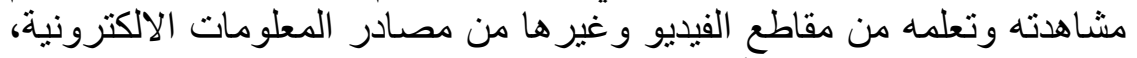

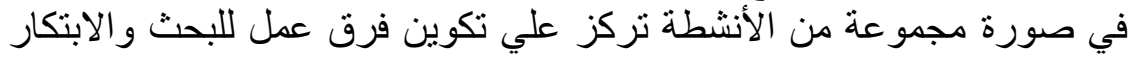

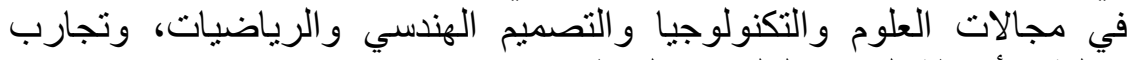
عملية، وأنشطة التفكير العلمي، والتومئو المنطقي. وتلخص الباحثة تلك الخطوات من خلال الثكل التير التيلي:

\begin{tabular}{|c|c|}
\hline \multicolumn{2}{|c|}{ المثيازكة التجزيبية داخل الفصل } \\
\hline تلتفِذ متروعات علمبية & الأنتسطة الليدوية \\
\hline الأبداع التخضصي & التَبراب \\
\hline \multicolumn{2}{|c|}{ اكتشاف المفاهيم خازج الفصل (بالمنزل) } \\
\hline متساهدة الفيديو هات & اخنبازر ات \\
\hline المدونات & 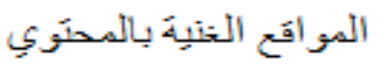 \\
\hline
\end{tabular}

\section{شكل( ) خطوات تطبيق أنشطة STEM وفق الصفوف المقلوبة}

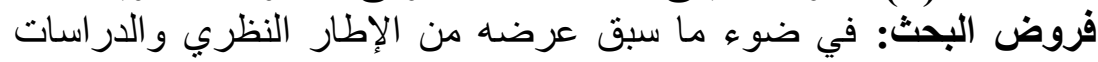

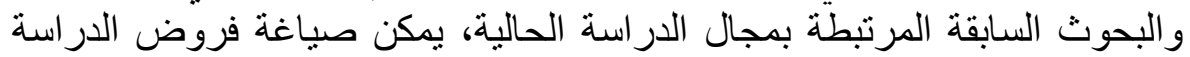

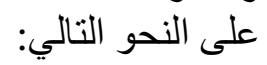

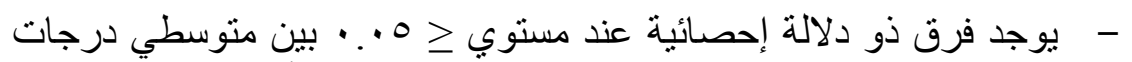

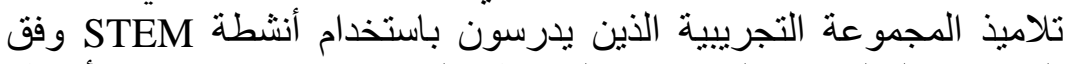

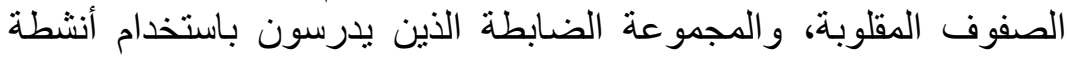
STEM المجمو عة التجريبية.

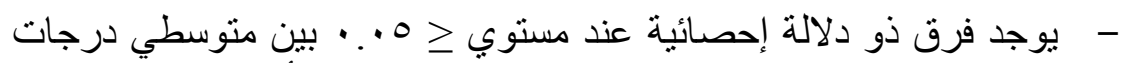
تلاميذ المجموعة التجريية الذين يدرسون باستخدام أنشطة STEM دون 
الصفوف المقلوبة، والمجموعة الضابطة الذين يدرسون باستخدام أنشطة

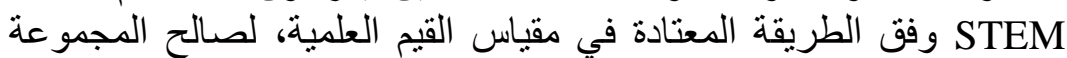

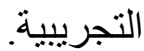
- - تحقق أنشطة STEM وفق الصفوف المقلوبة حجم تأثير مناسب في تتمية مهارات التفكير الأساسية في مادة العلوم. - - تحقق أنشطة STEM وفق الصفوف المقلوبة حجم تأثير مناسب في تتمية

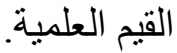

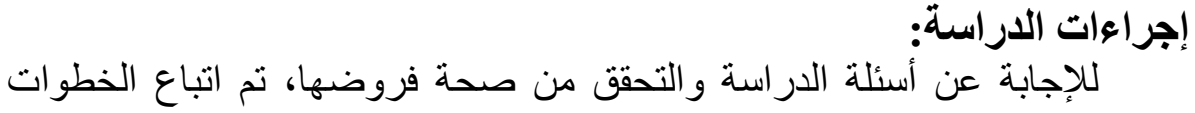

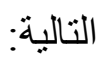

أولا: إعداد قائمة مهارات التفكير الأساسية في العلوم التي يمكن تنميتها

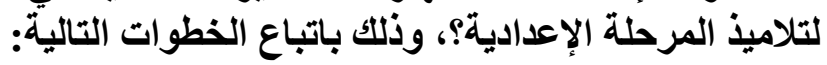

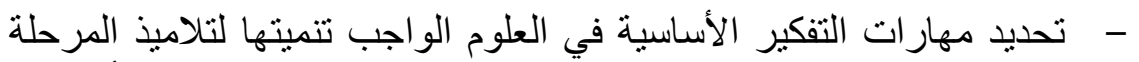

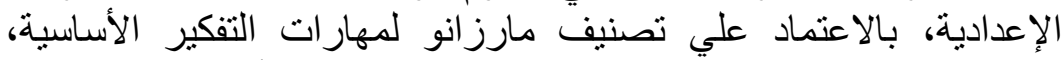

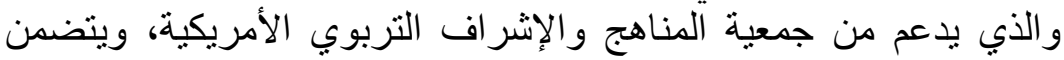

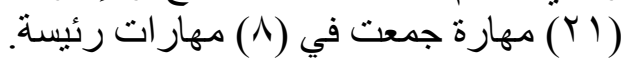

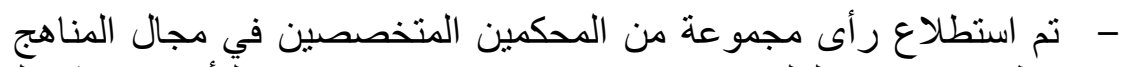

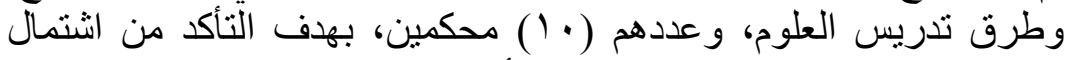

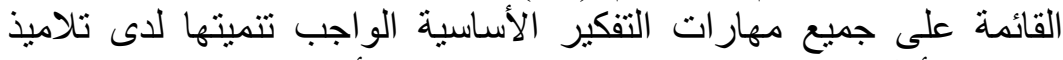
الصف الأول الإعدادي في مادة العلوم، وإضافة أو حذف بعض الزف المهار التهات

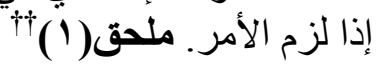

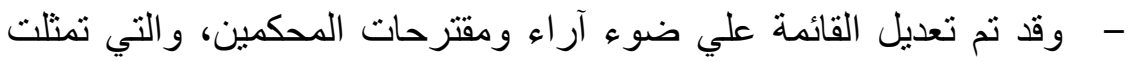

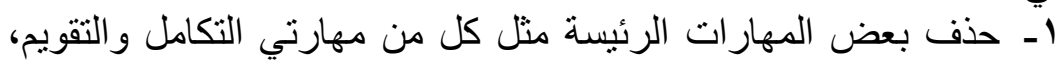

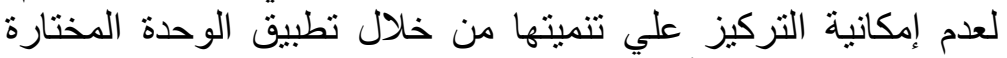

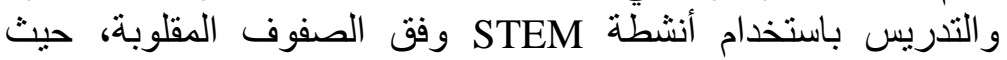

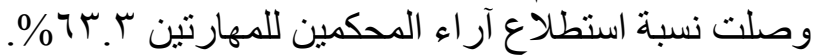

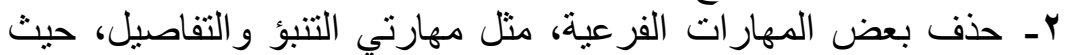

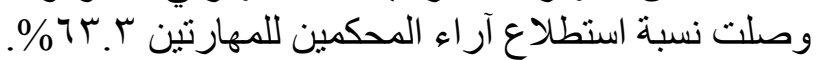
r- بط المهار ات الفرعية بتخصص آنص العلوم.

†+ ملحق( (1) استطلاع آراء المحكمين حول مهارات التقكير الأساسية في العلوم الواجب تتميتها لتلاميذ المرحلة الإعدادية 


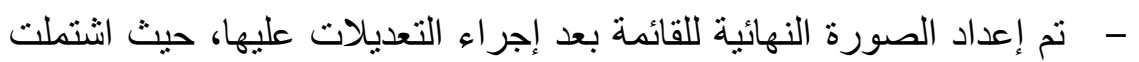

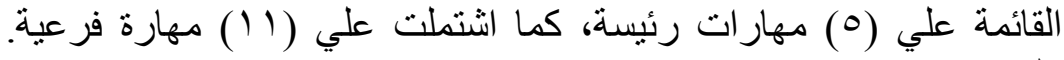
ملحق(r)

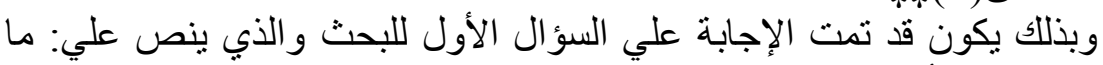

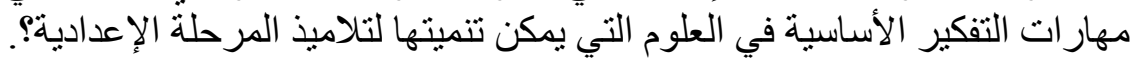

ثانيا: إعداد قائمة القيم العلمية التي يمكن تنميتها لتلاميذ المرحلة الإعدادية، وذلك

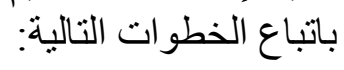

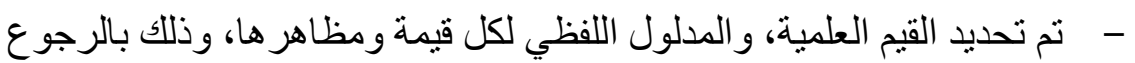

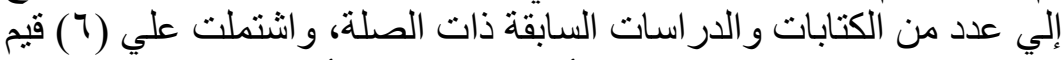

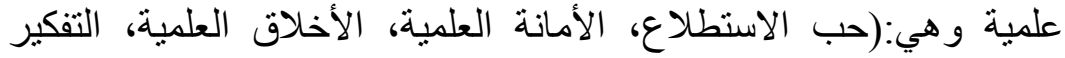
العلمي، تقدير العلم، تقدير العلماء).

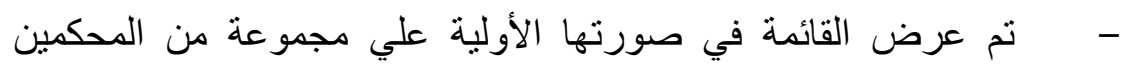

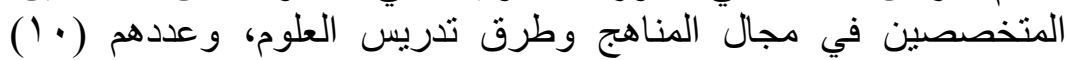

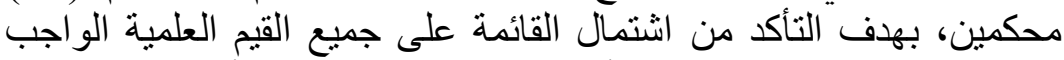

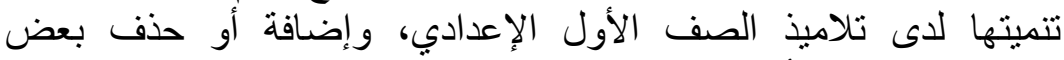

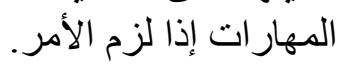
وقد اتفقت آراء المحكمين على أهمية تلك القيم التهم التلاميذ المرحلة الإعدادية،

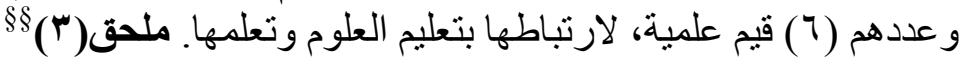

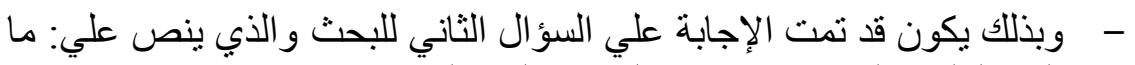
القيم العلمية التي يمكن تنميتها لتلاميذ المرحلة الإعدادية؟؟ التها

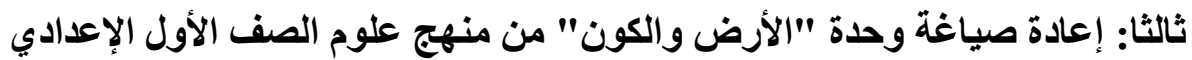

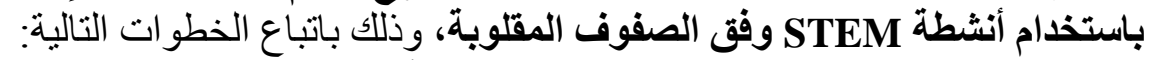

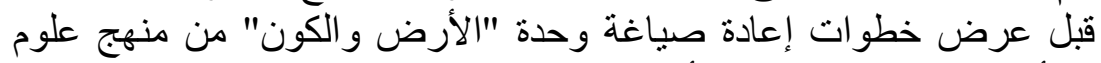

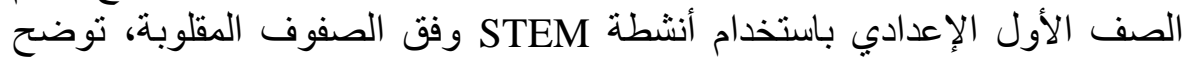

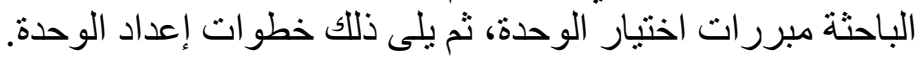

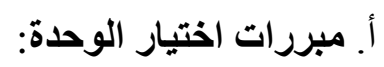

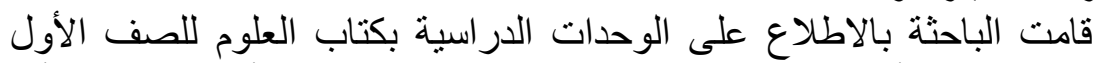

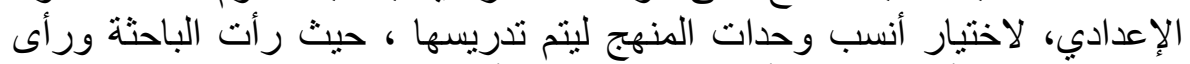
معها المحكمون أن وحدة " الأرض و الكون النون" من أكثر الوحدات ملاعمة لتنمية:

抽 ملحق(Y) الصورة النهائية لقائمة مهارات التفكير الأساسية في العلوم الواجب تتميتها لتلاميذ المرحلة الإعدادية

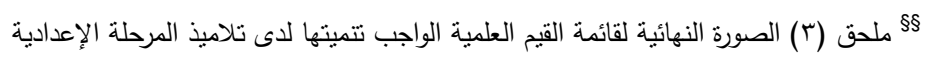

المجلة المصرية للتربية العمية 
مهار ات التفكير الأساسية والقيم العلمية لدى تلاميذ الصف الأول الإعدادي باستخدام

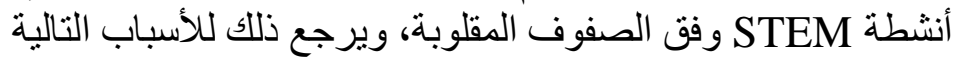

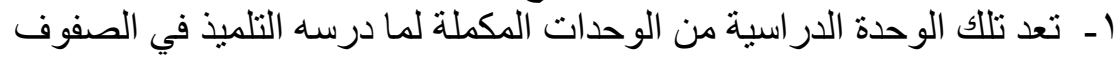

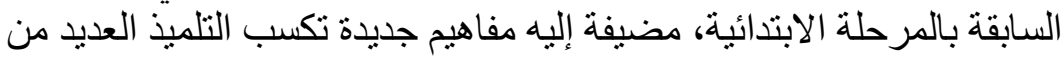
القيم العلمية. r- إمكانية تكوين فرق عمل للبحث و الابتكار في مجالات العلوم والتكنولوجيا

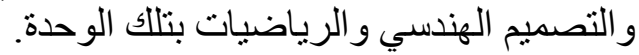

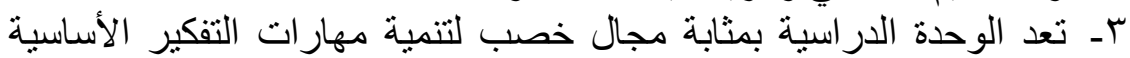

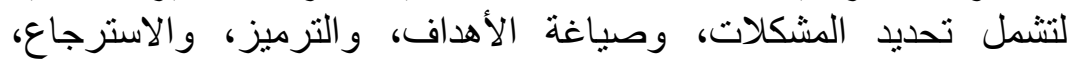

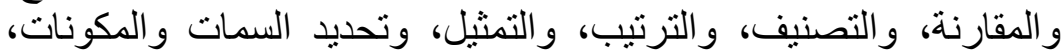

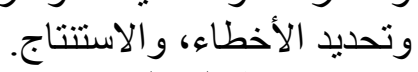

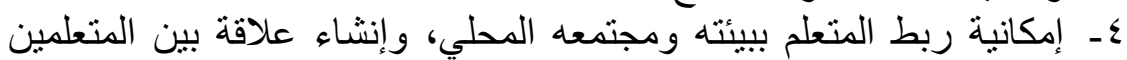

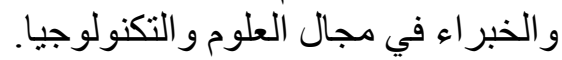

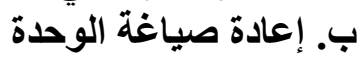

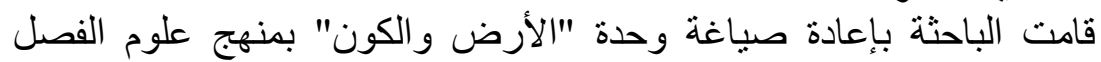
الدراسي الثاني للصف الأول الإعدادي باستخدام أنشطة

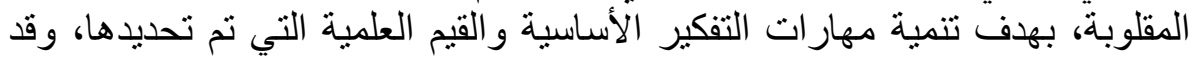

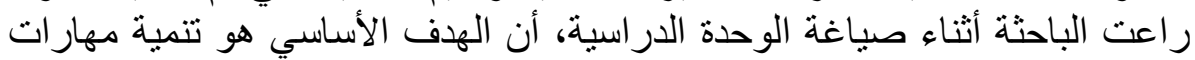

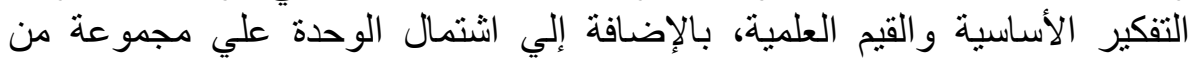

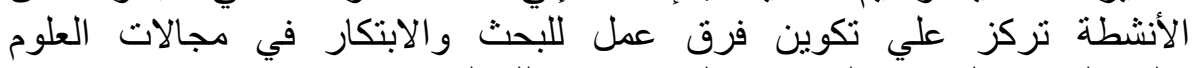
و التكنولوجيا و التصميم الهندسي و الرياضيات بتلكي الوحدة. لأنئ.

وتتمثل خطوات إعداد وحدة "الأرض و الكون" باستخدام أنشطة STEM وفق الصفوف المقلوبة، في المر احل التالية: المرحلة الأولي: كتابة سيناريو مقاطع الفيديو، لوحدة " الأرض والكون" بمرحلة اللقاء قبل الصفي.

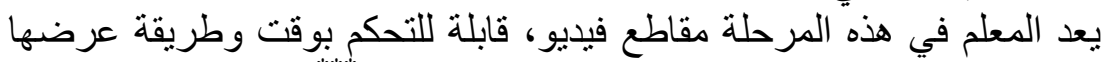

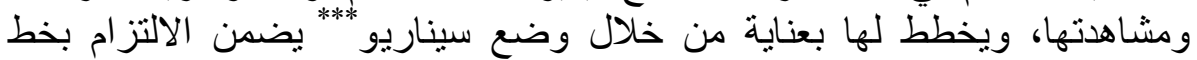

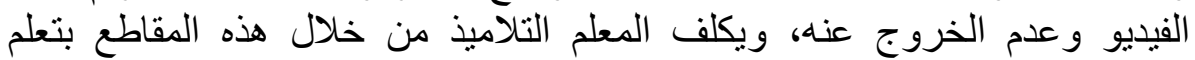

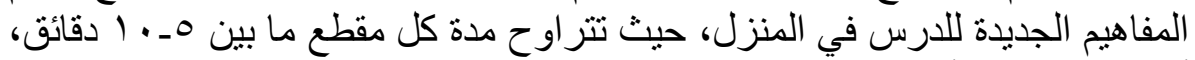

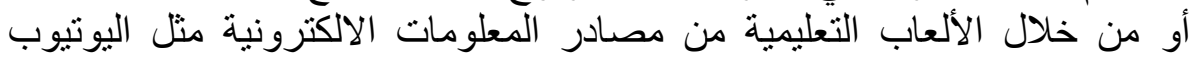

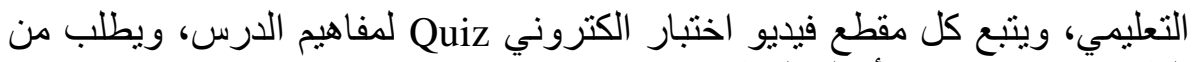
الطلاب الإجابة عن الأسئلة المطروحة فيو النئ.

"* ملحق(ع) سيناريو مقاطع الفيديو لوحدة "الأرض و الكون" لتلاميذ المرحلة الإعدادية

المجلة المصرية للتربية العلمية 
المرحلة الثانية: إعادة صياغة الوحدة باستخدام أنشطة STEM وفث

الصفوف المقلوبة.

في هذه المرحلة قامت الباحثة بإعادة صياغة وحدة "الأرض و الكون" بمنهج

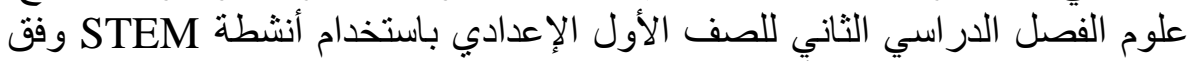

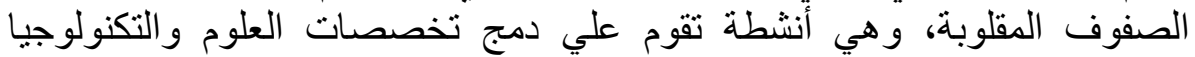

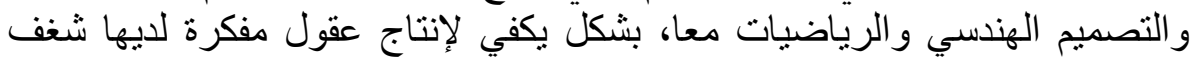

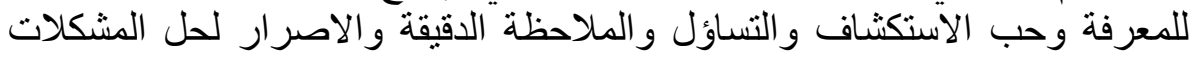

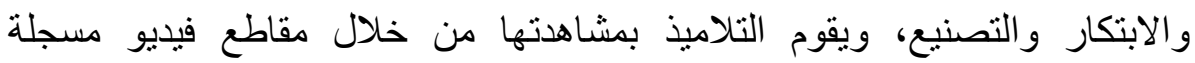

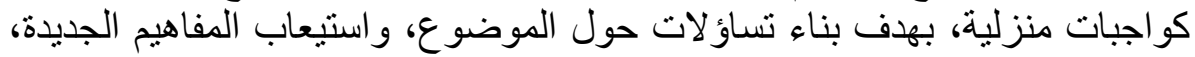

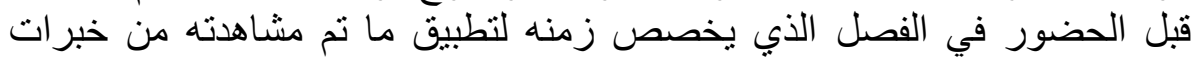

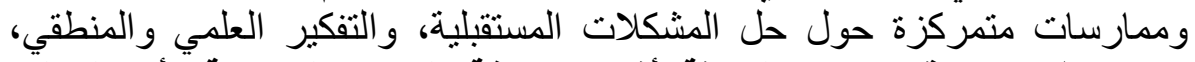

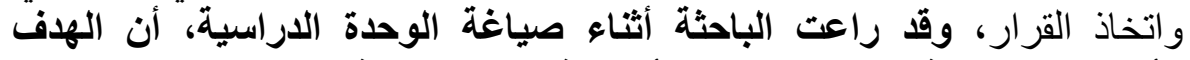

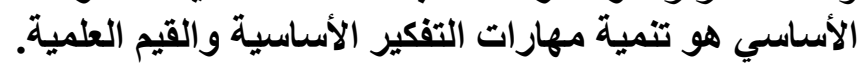

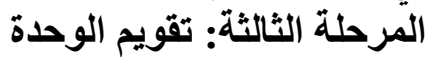

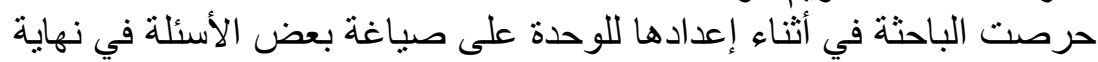

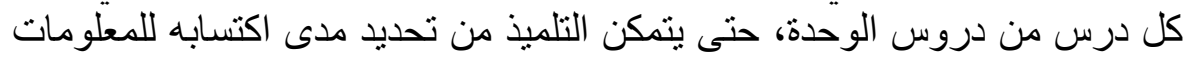

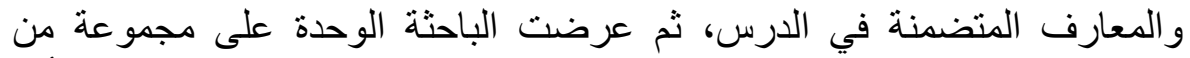

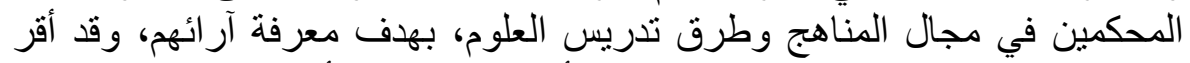

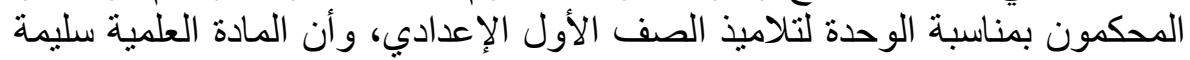

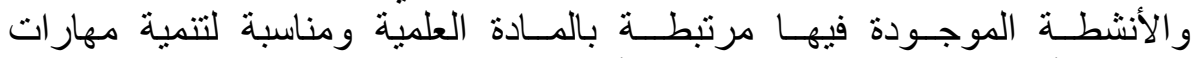

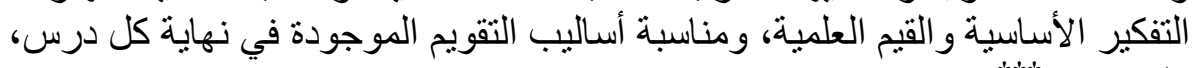
ملحق (0)

ج. إعداد دليل المعلم في وحدة "الأرض والكون" من منهج علوم الفصل

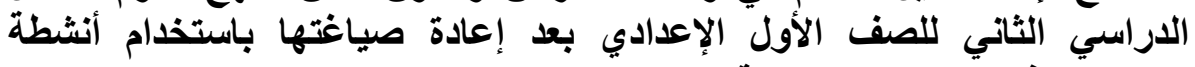
STEM

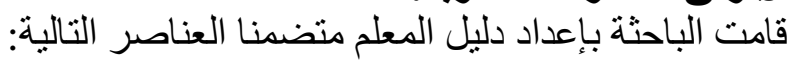

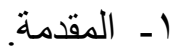

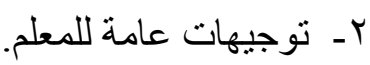

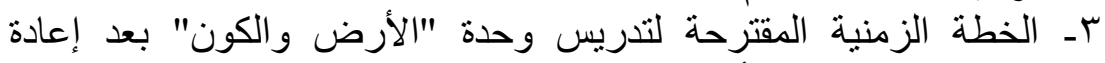

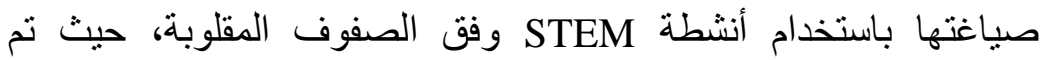

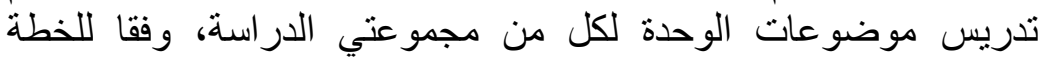

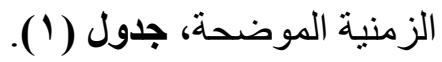

†t+ملق (0) الصورة النهائية لوحدة "الأرض والكون" باستخدام أنشطة STEM وفق الصفوف المقلوبة.

المجلة المصرية للتربية العلمية 
جدول( ) الخطة الزمنية المقترحة لتدريس الوحدة

\begin{tabular}{|c|c|c|}
\hline عدد الحصص & الموضوعات & الوحدة الدراسية \\
\hline r & الأجر ام السماوية. & \multirow[t]{4}{*}{ الأرض والكون } \\
\hline$r$ & كوكب الأرض. & \\
\hline$\mu$ & الصخور و المعادن. & \\
\hline$\mu$ & الز لازل و البر اكين. & \\
\hline r| حصة & & \\
\hline
\end{tabular}

$$
\begin{aligned}
& \text { عـ - جوانب التعلم المتضمنة بوحدة " الأرض و الكون". }
\end{aligned}
$$

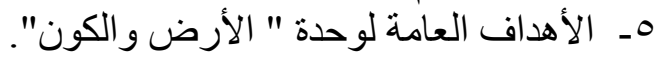

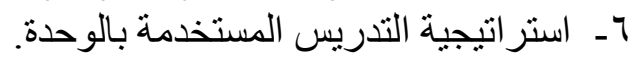

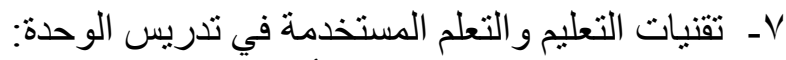

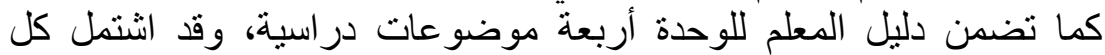

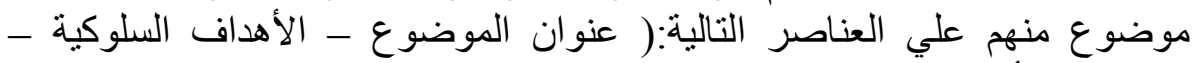

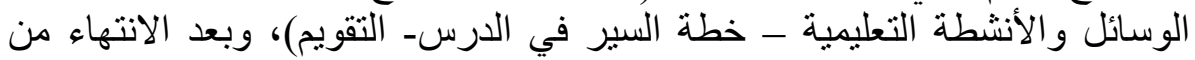

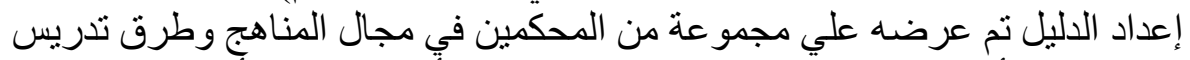

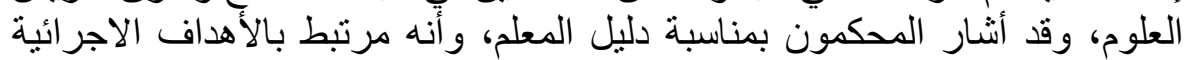

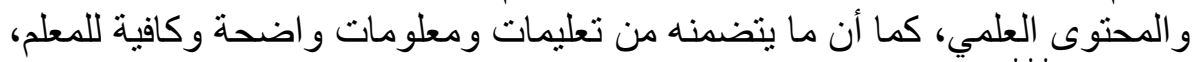

رابعا: بناء اختبار مهارات التفكير الأساسية في العلوم لتلاميذ الصف الأول الإعدادي.

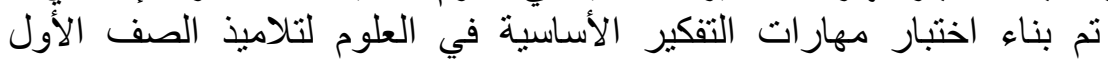
الإعدادي، وفقا للخطو ات التبار التالية:

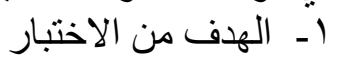

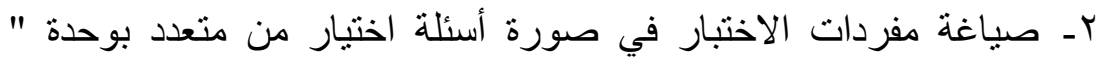

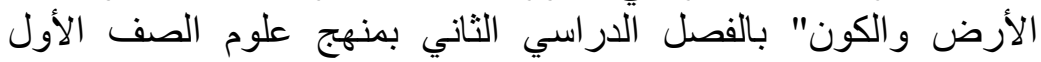

$$
\begin{aligned}
& \text { الإعدادي. } \\
& \text { r- جدول مو اصفات الاختبار. } \\
& \text { ع - صياغة بنود الاختبار. } \\
& \text { هـ إجر اء التجربة الاستطلاعية. }
\end{aligned}
$$

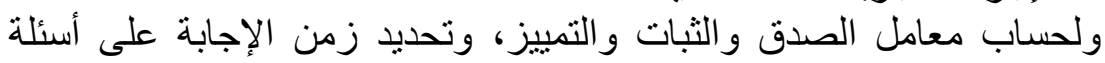
الاختبار ومدى وضو حس تعليماته، تم اتباع ما يلي:

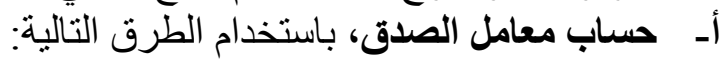




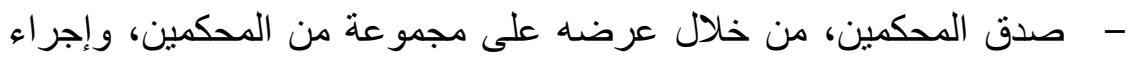

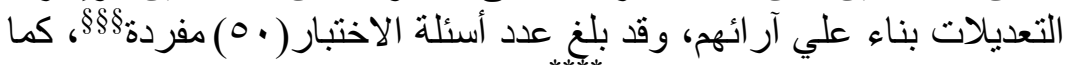

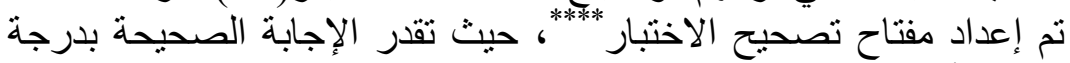

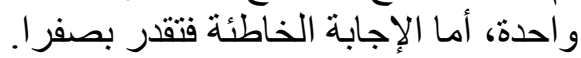

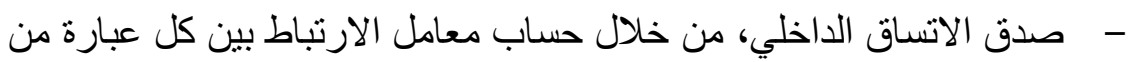

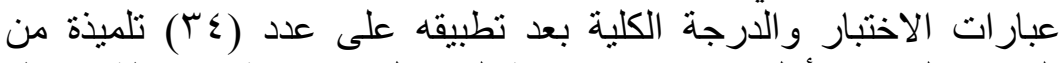
تلميذات الصف الأول الإعدادي بمدرسة المستقبل الإعدادية بمحافظة دمياط، بكان

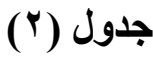

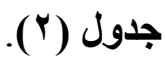

\section{معامل الارتباط بين كل عبارة من عبارات الاختبار والدرجة الكلية ل ل اختبار}

\begin{tabular}{|c|c|c|c|c|c|}
\hline مستوى الالالة & $\begin{array}{c}\text { معامل الارتباط } \\
\text { (ر) }\end{array}$ & العبارة & مستوى الدلالة & $\begin{array}{c}\text { معامل الارتباط } \\
\text { (ر) }\end{array}$ & العبارة \\
\hline$\because \cdot 1$ & $\because \wedge \varepsilon r$ & $r q$ & $\because \cdot 1$ & $\because \wedge 0 \leq$ & 1 \\
\hline$\because \cdot 1$ & $\because v \leqslant 7$ & $r V$ & $\because \cdot 1$ & $\because V \leq \Lambda$ & $r$ \\
\hline$\because \cdot 1$ & $\because V \otimes \Lambda$ & $r \wedge$ & $\because+1$ & $\because V Y \varepsilon$ & $r$ \\
\hline$\because \cdot 1$ & $. V \leq Y$ & rq & $\because \cdot 1$ & $.7 \% V$ & $\xi$ \\
\hline$\because \cdot 1$ & $\cdot \wedge \leq \mu$ & $r$. & $\because \cdot 1$ & $\because 0 \leq 9$ & 0 \\
\hline. .1 & $\cdot . \wedge Y V$ & $r 1$ & $\because+1$ & . & 7 \\
\hline$\because \cdot 1$ &. $.71 \varepsilon$ & rr & $\because \cdot 1$ & $\because \vee \wedge 0$ & V \\
\hline$\because \cdot 1$ &. .719 & $r r$ & $\because \cdot 1$ & $. v \leq r$ & $\Lambda$ \\
\hline$\because \cdot 1$ & $\because \vee \wedge \uparrow$ & $r \leq$ & $\because \cdot 1$ & $\because V 9 r$ & 9 \\
\hline$\because+1$ & $. V \leq 7$ & ro & $\because+1$ &.$V R Y$ & 1. \\
\hline$\because \cdot 1$ & $\cdot V \leqslant Y$ & $r q$ & $\because \cdot 1$ & $.0 \leqslant Y$ & 11 \\
\hline$\because \cdot 1$ &. $.70 \mathrm{~V}$ & $r v$ & $\because \cdot 1$ & $. .7 \leq 7$ & ir \\
\hline$\because \cdot 1$ & $.7 Y \leq$ & $r \wedge$ & $\because+1$ & $\because \vee \bullet \wedge$ & ir \\
\hline. .1 & $\because 0 \leq 9$ & $r q$ & $\because \cdot 1$ & $.0 \leq r$ & $1 \leqslant$ \\
\hline. .1 & $.7 r \varepsilon$ & $\varepsilon$. & $\because \cdot 1$ & $\because V \leq \varepsilon$ & 10 \\
\hline$\because \cdot 1$ &..$T V Y$ & \&1 & $\because 0$ & $.0 \leq 7$ & 17 \\
\hline$\because+1$ &. .701 & $\leqslant r$ & $\because .0$ &. .774 & IV \\
\hline$\because \cdot 1$ & $\because .7 \wedge \mathrm{V}$ & $\varepsilon r$ & $\because 0$ & $.0 \wedge \varepsilon$ & 11 \\
\hline$\because \cdot 1$ & $\because V \leq q$ & $\leq \varepsilon$ & $\because \theta$ & $. .79 \leq$ & 19 \\
\hline
\end{tabular}

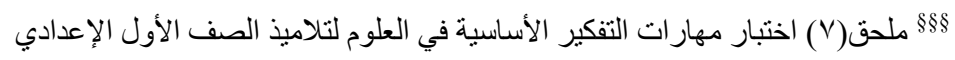

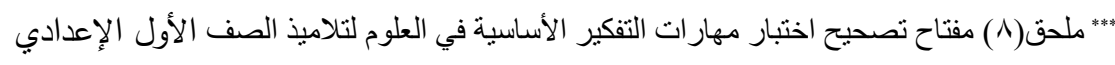




\begin{tabular}{|c|c|c|c|c|c|}
\hline مستوى الدلاية & 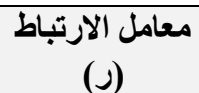 & العبارة & مستوى & $\begin{array}{c}\text { معامل الارتباط (ر) } \\
\text { (ر) }\end{array}$ & رقامث \\
\hline$\because \cdot 1$ & . TVY & $\leqslant 0$ & $\because \cdot 1$ & $\cdot . \vee 4 r$ & $r$ \\
\hline$\because 0$ & דY & $\leqslant 7$ & $\because \cdot 1$ &. $.7 r$. & YI \\
\hline$\because 0$ & $\because \leqslant O r$ & $\varepsilon V$ & $\because \cdot 1$ &..$T \wedge r$ & Yr \\
\hline$\because .0$ & $\because \leqslant 90$ & $\varepsilon \Lambda$ & $\because 0$ & .099 & $r r$ \\
\hline$\because 0$ & $\because \leqslant O V$ & $\varepsilon 9$ & $\because .0$ & .740 & $r \xi$ \\
\hline$\because .0$ &. .597 & 0. &. .1 &.$V \cdot 0$ & ro \\
\hline
\end{tabular}

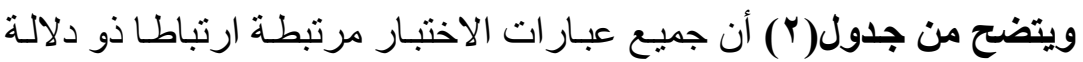

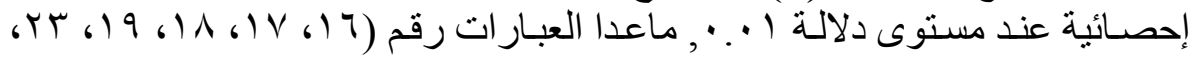
§

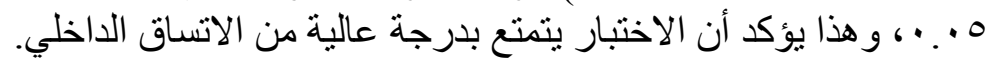

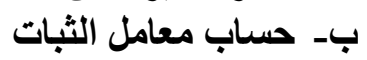

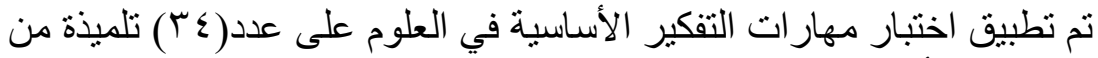

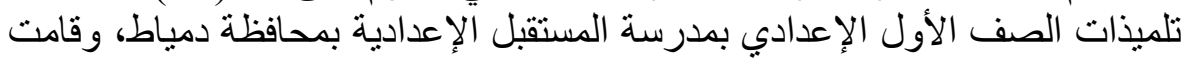

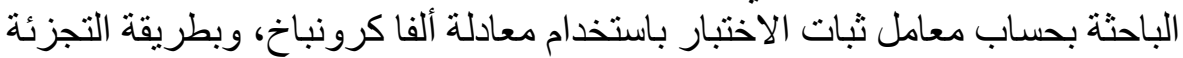

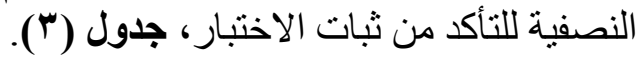

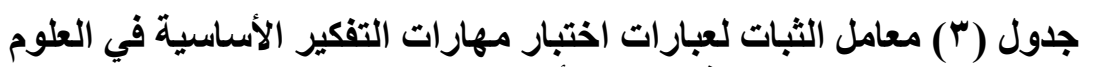
لتلاميذ الصف الأول الإعدادي مئات التيات

\begin{tabular}{|c|c|c|c|c|c|c|}
\hline \multirow{2}{*}{ كعامل ألفا } & \multirow{2}{*}{ الارتباط } & \multicolumn{2}{|c|}{ العبارات الزوجية } & \multicolumn{2}{|c|}{ العبارات الفردية } & \multirow{2}{*}{ عدد العبار ات } \\
\hline & & $\varepsilon$ & b & $\varepsilon$ & b & \\
\hline 9 & . & Y.00 & 17.78 & r. 9.9 & 10.rr & 0. \\
\hline
\end{tabular}

ويتضح من جدول (ّ) أن معامل ثبات الاختبار بلغ بطريقة التجزئة النصفية (47V) بلغ ( q T. · ) ), و هذا يؤكد أن معامل ثبات الاختبار مرتفع. 
ج. حساب معامل السهولة والصعوبة والتمييز، وتبين أن معاملات السهولة

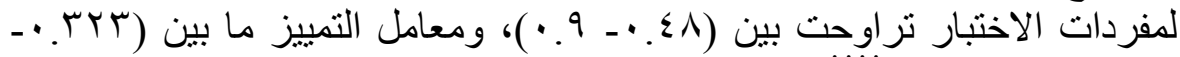

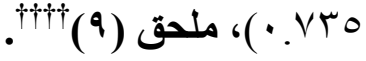

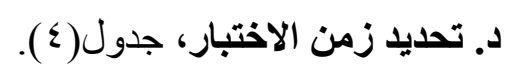

جدول (؛ ) حساب زمن اختبار مهارات التفكير الأساسية في العلوم لتلاميذ الصف الأول الإعدادي مئب التاري

\begin{tabular}{|c|c|c|}
\hline متزوسط & متوسط زمن الألين يمثلون الإرباعى الأعلى زمنا & متوسط زمن الأنين يمثلون \\
\hline ro & $\varepsilon$. & $r$ \\
\hline
\end{tabular}

ويتضح من جدول (ع ) أن الزمن المناسب للاختبار هو(0ب) دقيقة.

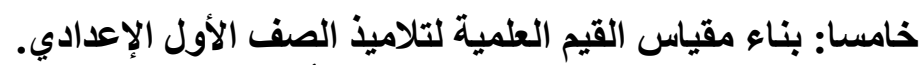

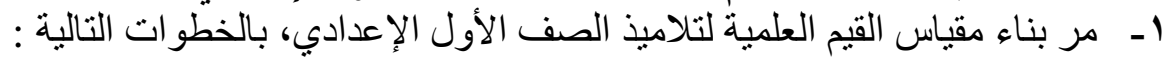
r ب الهدف من المقياس.

r- صياغة مفردات المقياس، في صورة عدد من المو اقف التي يو اجهها الفرد، وذلك

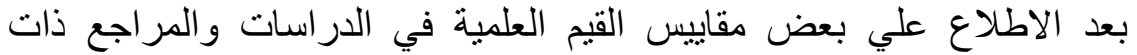
الصلة، ووضع ثلاث بدائل كحلول للموقف العلمي، يختار التلميذ منها ما ير الهاه

$$
\text { ع- ـدول مو اصفات الاختبار. }
$$

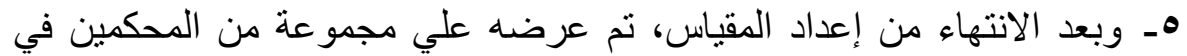

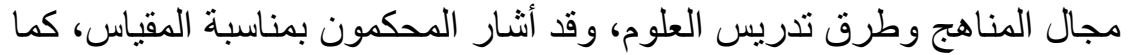

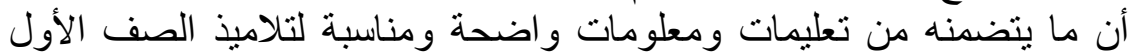

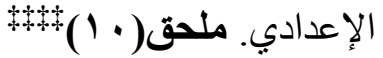

$$
\begin{aligned}
& \text { 1- طريقة تصحيح الاختبار. }
\end{aligned}
$$

قامت الباحثة بصياغة مفردات الاختبار بلتبار في عدد من المو اقف، ولكل موقف

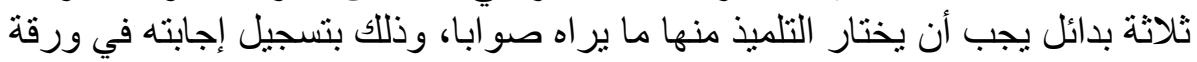

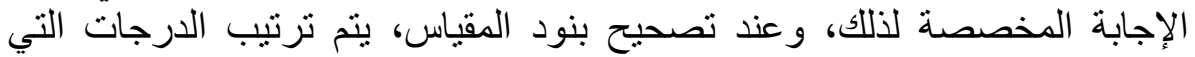

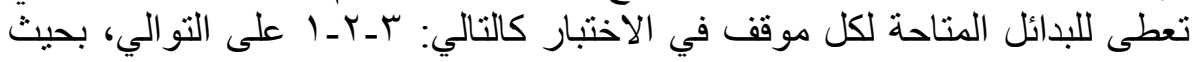

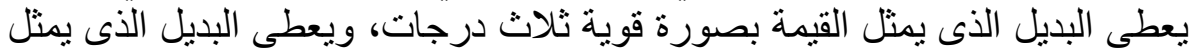

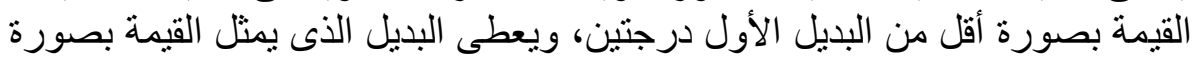

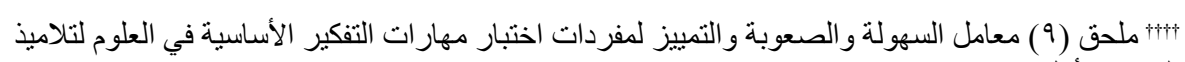

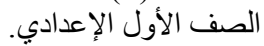

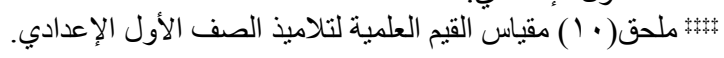


ضعيفة درجة واحدة، وتقاس درجات التلميذ على المقياس من خلال حساب مجموع درجاته على مو اقف المقياس. V - إجر اء التجربة الاستطلاعية للمقياس.

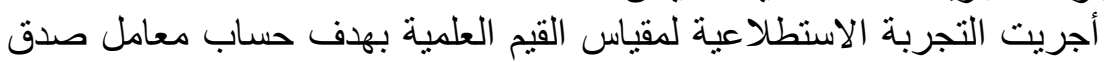
المقياس وثباته، وفيما يلي نتائج التجربة الاستطلاعية:

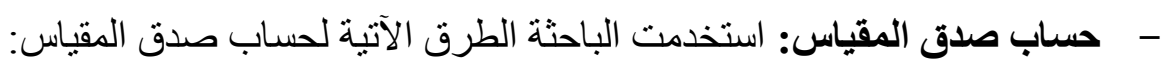

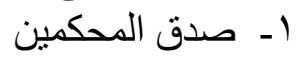

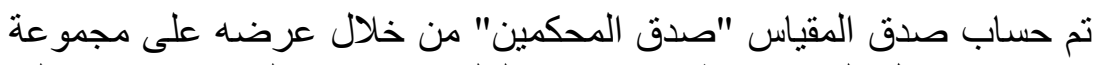

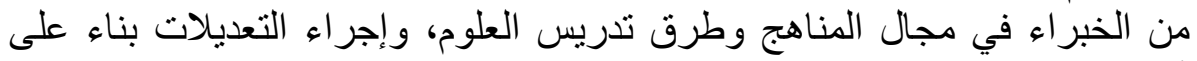

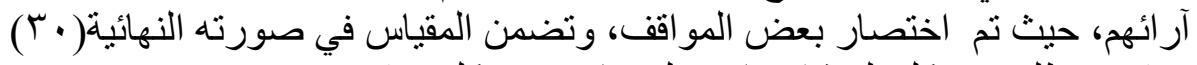

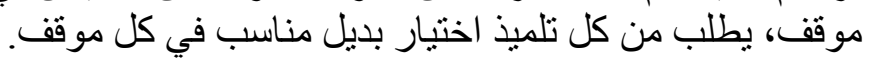

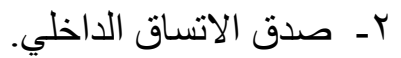
تم حساب معامل الارتباط بين كل موقف من مواقف المقياس والدرجة الكلية

للمقياس، جدول(0).

جدول(ه) معامل الارتباط بين كل موقف من مواقف مقياس القيم العلمية

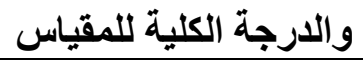

\begin{tabular}{|c|c|c|c|c|c|}
\hline مستوى الدلالة & $\begin{array}{c}\text { معامل الارتباط (ر) } \\
\text { (ر) }\end{array}$ & رقمث & مستوى الدلالة & $\begin{array}{c}\text { معامل الارتباط } \\
\text { (ر) }\end{array}$ & الموقفت \\
\hline$\cdot, \cdot 0$ & , Orr & 18 & $\cdot, \cdot 0$ & $\cdot . \leqslant q q$ & 1 \\
\hline$\because .0$ &. $.71 Y$ & IV & $\because .0$ & $\because 809$ & $r$ \\
\hline$\because .0$ &. $.7 \wedge V$ & 11 & $\because .0$ & $\cdot \varepsilon V T$ & $r$ \\
\hline$\because \cdot 0$ &..$T V Y$ & 19 & $\because .0$ &. $.7 r v$ & $\varepsilon$ \\
\hline$\because .0$ & $.0 Y 7$ & $r$. & $\because .0$ & $.07 \leq$ & 0 \\
\hline$\because .0$ & $\because \leqslant O Y$ & YI & $\because .0$ &. $.79 V$ & 7 \\
\hline$\because 0$ &. .290 & rr &. .0 & $. V \leq 7$ & $\mathrm{~V}$ \\
\hline$\because .0$ & $\because V \circ r$ & $r r$ & $\because .0$ &. .207 & $\Lambda$ \\
\hline$\because .0$ & .740 & $r \varepsilon$ & $\because .0$ & $\because \leqslant 0 V$ & 9 \\
\hline$\because .0$ & $\because E V Y$ & ro & $\because .0$ &. .297 & 1. \\
\hline$\because .0$ & $.0 \leq 7$ & Y7 & $\because .0$ & $.7 \leq 9$ & 11 \\
\hline$\because .0$ & $\because 0 Y 7$ & TV & $\because .0$ & $.0 \leq 7$ & Ir \\
\hline$\because .0$ & $\because \varepsilon O r$ & rA & $\because .0$ & .974 & 14 \\
\hline$\because .0$ &. .290 & rq & $\because .0$ & $.0 \wedge \varepsilon$ & $1 \varepsilon$ \\
\hline$\because \cdot 0$ & OrV & $r$. & $\because \cdot \theta$ & $. .79 \leq$ & 10 \\
\hline
\end{tabular}

- - 
جدول (") معامل ثبات مقياس القيم العلمية لتلاميذ الصف الأول

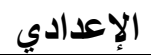

\begin{tabular}{|c|c|c|c|}
\hline معامل الثبات & عدد مواقف المقياس & الارجة الكلية & \\
\hline$\because v 01$ & $r$. & 9. & المقياس \\
\hline
\end{tabular}

ويتضح من جدول (T) أن معامل ثبات المقياس يبلغ (V01. • )، وهو معامل

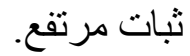
- - حساب معامل التمييز لكل موقف من مواقف المقياس، وتبين أن معامل التمييز

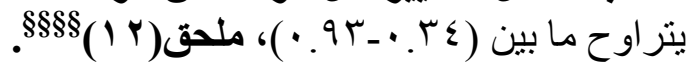

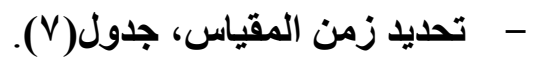

جدول (V) حساب زمن مقياس القيم العلمية لتلاميذ الصف الأول

\begin{tabular}{|c|c|c|}
\hline متوسط الزمن & يمثلون الإرباعى الأعلى زمنـا & يمثلون الإرباعى الأقل زمنا الذين \\
\hline TO & $r_{0}$ & 10 \\
\hline
\end{tabular}

- - مضوح تعليمات المقياس ومعانى مفرداتها.

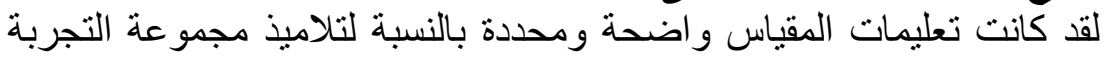
الاستطلاعية للاختبار، كما كانت مفرداته و اضحة المعاني ولمة ولم تثر جدلا بين التلاميذ. سادسا: إجراعات الاراسة التجريبية

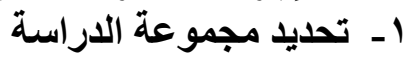

تم اختيار مجموعة الدر اسة التجريبية من تلاميذ مدرسة بنت الثناطئ الإعدادية التباية

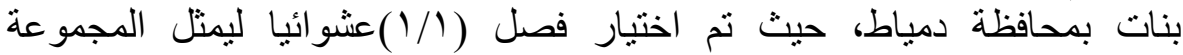

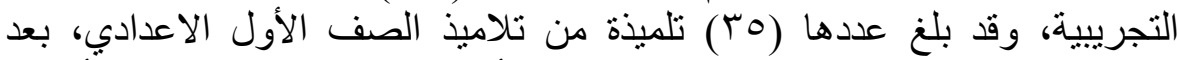

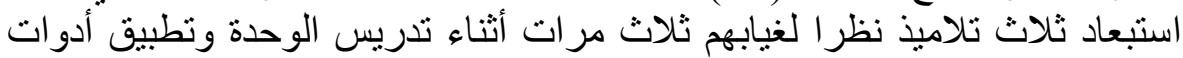

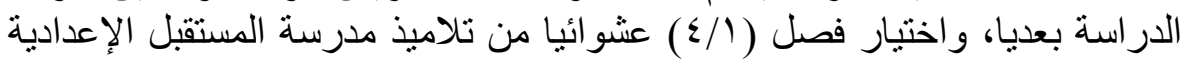

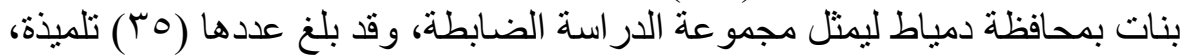
وذللك بعد استبعاد فصل (Y/I) بتلك المدرسة نظرا لتطبيق الدراسة الاستطلاعية علي هذا الفصل.

\$\$\$§ ملحق (r I ) معامل التمييز لمواقف مقياس القيم العلمية لتلاميذ الصف الأول الإعدادي 


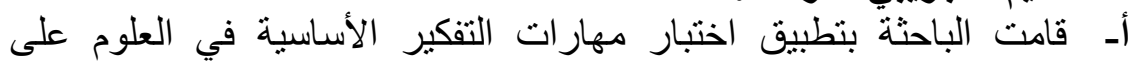

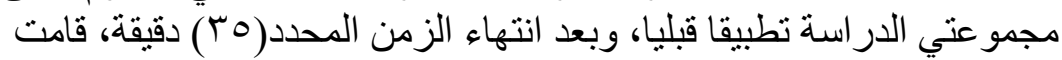

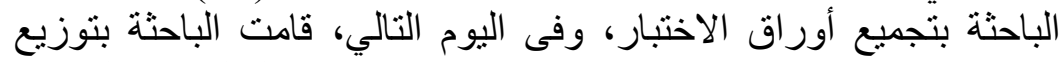

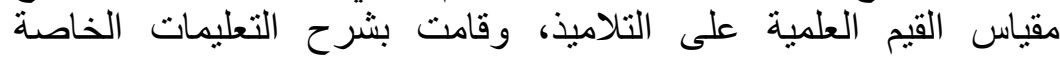

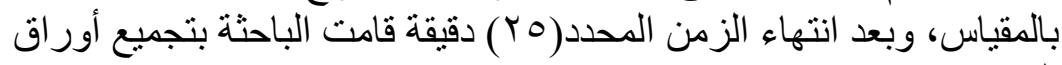

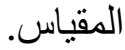

بـ استغرق تدريس الوحدة التجريبية المصاغة باستخدام أنشطة

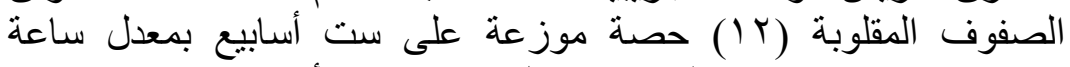

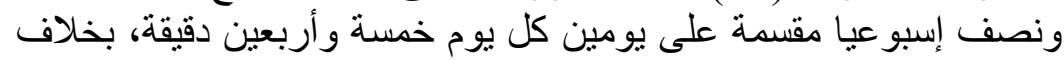

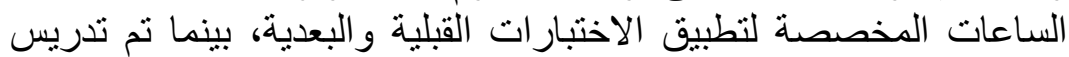

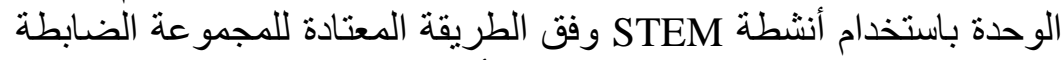

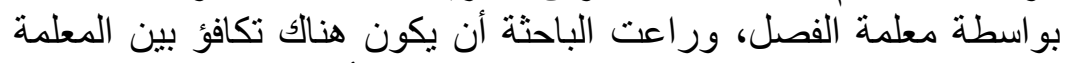

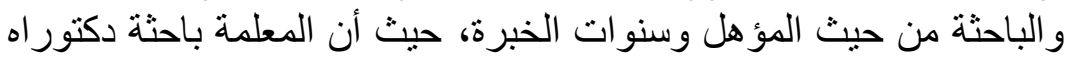

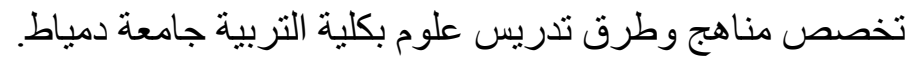

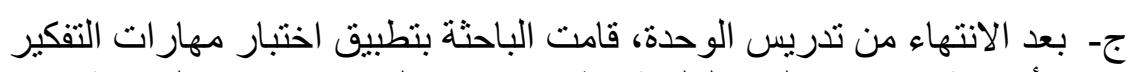

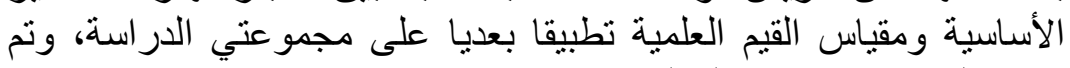

$$
\text { رصد الدرجات وإجر اء العمليات الاحصائية. }
$$

نتائج الاراسة وتفسيرها:

- تكافؤ المجموعتين التجريبية والضابطة في اختبار مهارات التفكير الأساسية القبلي، جدول(^) يوضح ذللك.

(^) جدول (^)

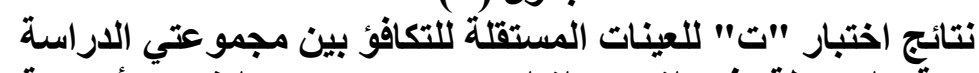

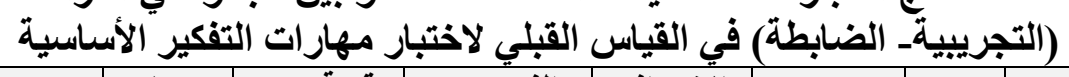

\begin{tabular}{|c|c|c|c|c|c|c|c|}
\hline مستوي & الدرجية & المحسمة (تية) & المتوسطين & المعياري & المتوسط & العدد & المجموعة \\
\hline \multirow[t]{2}{*}{.991} & \multirow[t]{2}{*}{71} & \multirow[t]{2}{*}{$\because r V_{0}$} & \multirow[t]{2}{*}{$\cdot r \leqslant Y \wedge$} & r.^o & $r \wedge . r$ & ro & تجريبية \\
\hline & & & & r.A. & YV.q & ro & ضابطة \\
\hline
\end{tabular}

\section{ويتضح من جدول(^) ما يلي:}

بلغ متوسط درجات تلاميذ المجموعة التجريبية في اختبار مهارات التهات التفكير

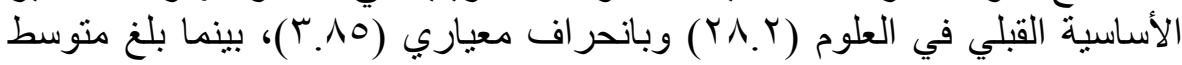

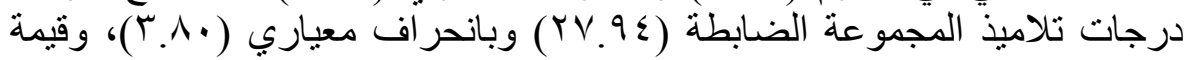

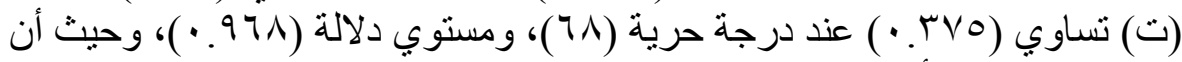

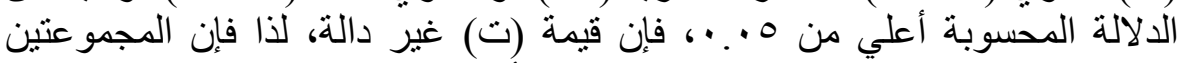
متكافئتين في الاختبار القبلي لمهار ات التفكير الأساسية في العلوم. هير. 
- اختبار صحة الفرض الأول: جدول(9) يوضح ذلك.

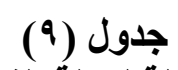

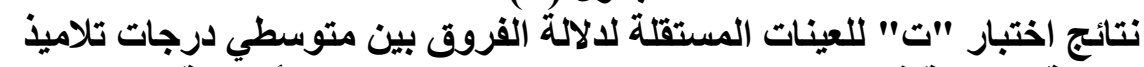

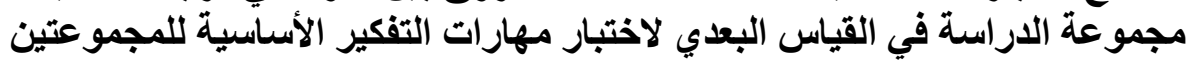
التجريبية والضابطة الإنة

\begin{tabular}{|c|c|c|c|c|c|c|c|c|}
\hline مستوّي & الحرية & قالمحسة (ت) & المتوق بين & الانعرافي المعياري & المئوية & المتوسط & العدد & المجموعة \\
\hline \multirow[t]{2}{*}{$\because \cdots 1$} & \multirow[t]{2}{*}{71} & \multirow[t]{2}{*}{$7 . Y V Y$} & \multirow[t]{2}{*}{$r . V \leq r$} & r.VVV & MY.A & $\leqslant 7 . \wedge 7$ & ro & تجريبية \\
\hline & & & & r.IVq & $r . .1 \wedge$ & $\{r .11$ & ro & ضابطة \\
\hline
\end{tabular}

$$
\text { ويتضح من جدول(9) ما فيلي: }
$$

- متوسط درجات تلاميذ المجموعة التجريبية في اختبار مهار مات التفكير الأساسية

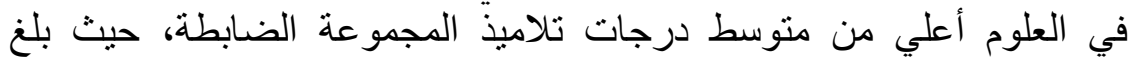

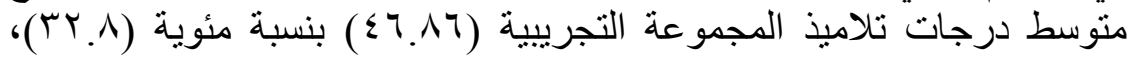

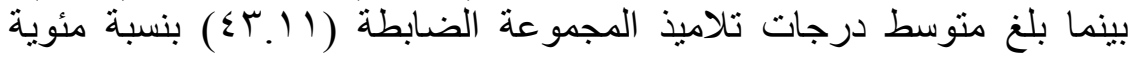

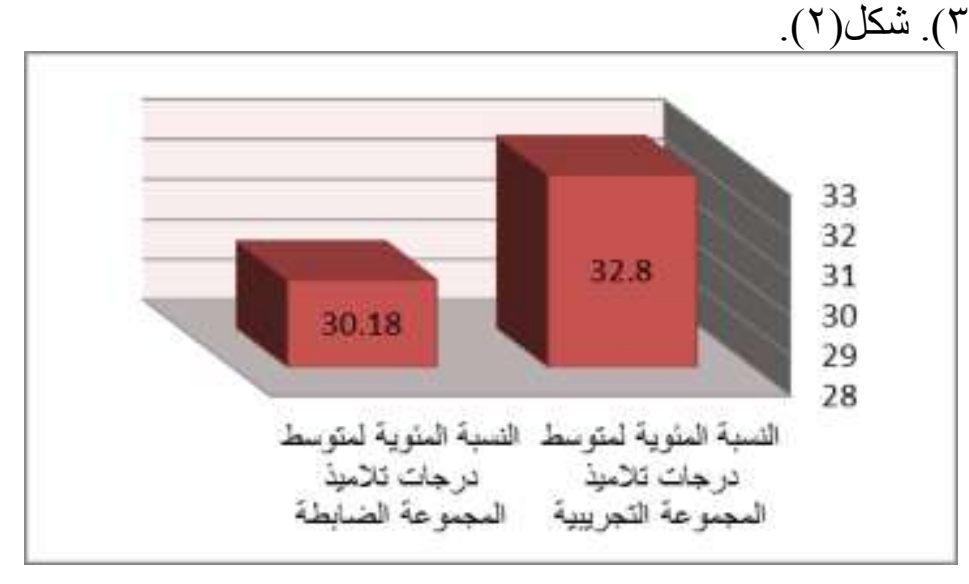

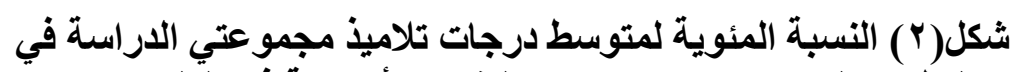

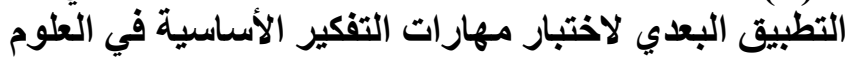

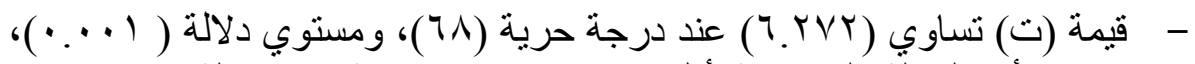

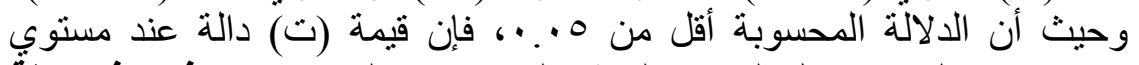

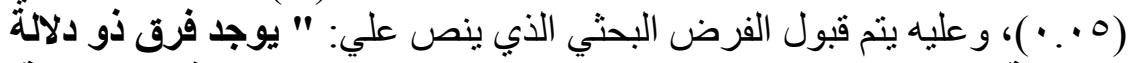

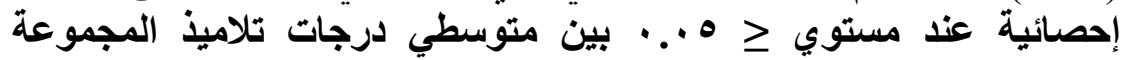

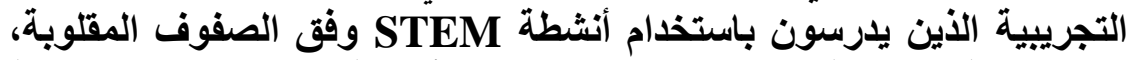
والمجموعة الضابطة الذين يدرسون بائن باستخدام أنشطة

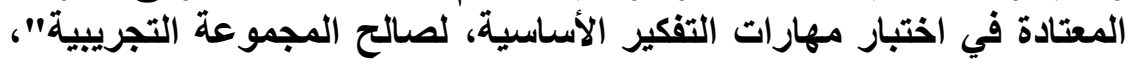


أي أن استخدام أنشطة STEM وفق الصفوف المقلوبة ذو أثز فعال في تتمية مهار ات التفكير الأساسية في العلوم لدي تلاميذ الصف الصف الأول الإعدادي.

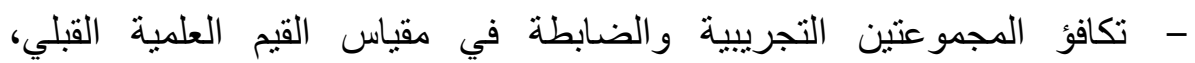

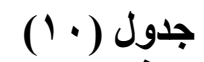$$
\text { جدول(· (1) يوضح ذللك. }
$$

نتائج اختبار "ت" للعينات المستقلة للتكافؤ بين مجموعتي الفي الاراسة (التجريبيةـ

\begin{tabular}{|c|c|c|c|c|c|c|c|}
\hline مستوي & الدرجية & قالمحسة (ت) & المتوسطين بين & الالمعراف & المتوسط & العلد & المجموعة \\
\hline \multirow[t]{2}{*}{ 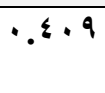 } & \multirow[t]{2}{*}{71} & \multirow[t]{2}{*}{$\because 9 \leqslant Y \wedge$} & \multirow[t]{2}{*}{1.10} & 9.79 & YY.IV & ro & تجريبية \\
\hline & & & & 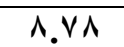 & rr.U1 & ro & ضابطة \\
\hline
\end{tabular}

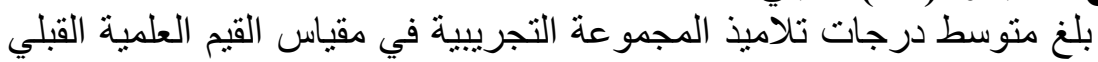

$$
\text { ويتضح من جدول(· · ( ) ما يلي: }
$$

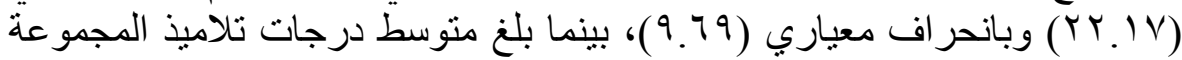

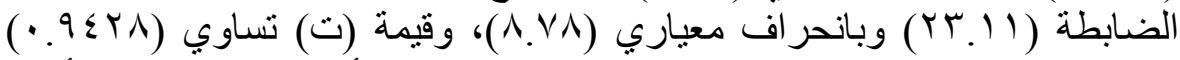

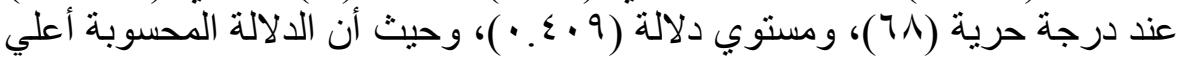

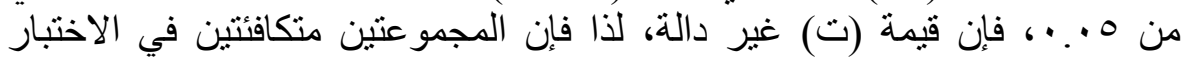
القبلي لمقياس القيم العلمية.

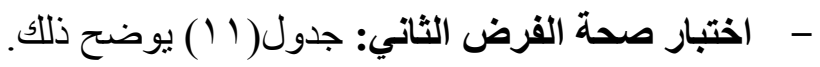

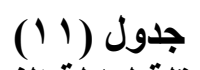

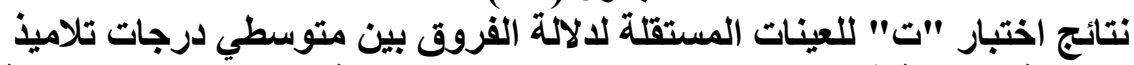

\begin{tabular}{|c|c|c|c|c|c|c|c|c|}
\hline مستوية الدلاية & الرجرية & قالمحسة (تبة) & المترسطين & الالمعراف & المئوية & المتوسط & العدد & المجموعة \\
\hline \multirow[t]{2}{*}{$\because \cdots 1$} & \multirow[t]{2}{*}{71} & \multirow[t]{2}{*}{$\varepsilon .1 \leq V$} & \multirow[t]{2}{*}{$0 . r \leq r$} & $0.7+1$ & $Y \nearrow . \wedge$ & $71.91 \leq$ & ro & تجريبية \\
\hline & & & & $0.1 \times 9$ & $r \varepsilon . V Y$ & Ir.0VI & ro & ضابطة \\
\hline
\end{tabular}
مجموعة الاراسة في القياس البعدي لمقياس القيم العلمية للمجموعتين لفين التجريبية والضابطة المقيان

\section{ويتضح من جدول(1 1 ) ما يلي:}

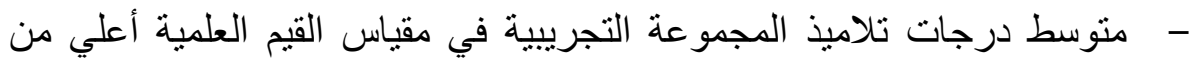

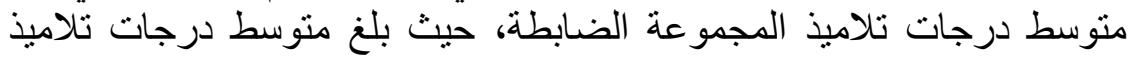

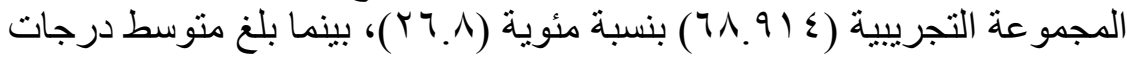

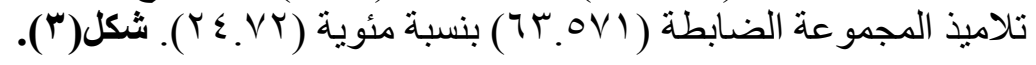




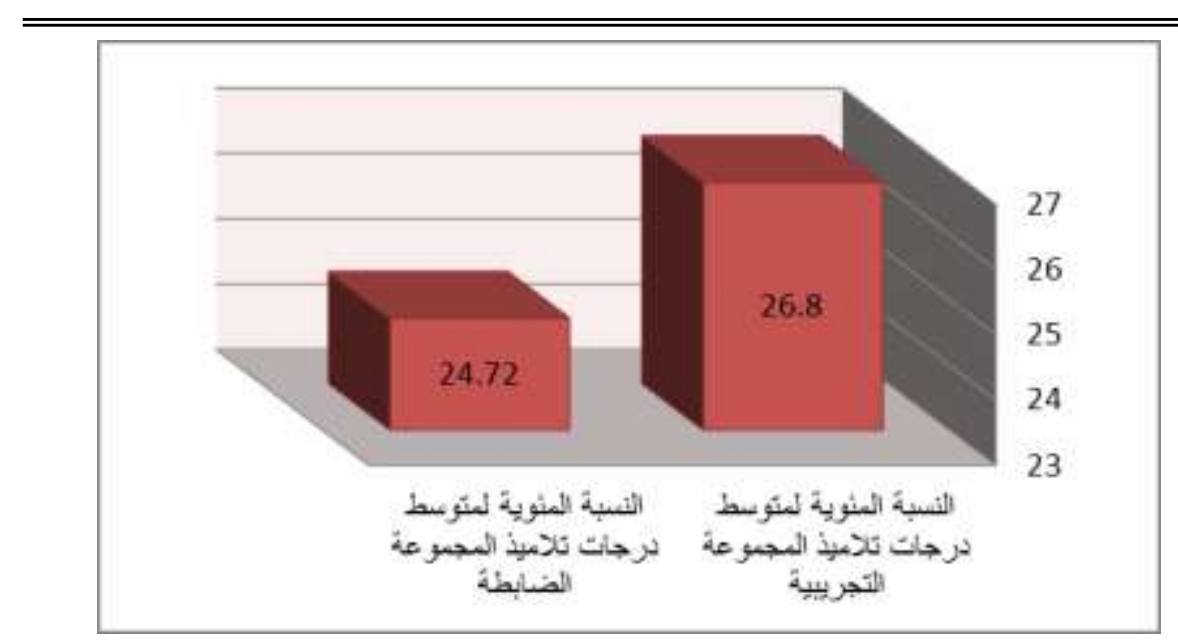

شكل(") النسبة المئوية لمتوسط درجات تلاميذ مجموعتي الدراسة في التطبيق البعدي لمقياس القيم العلمية

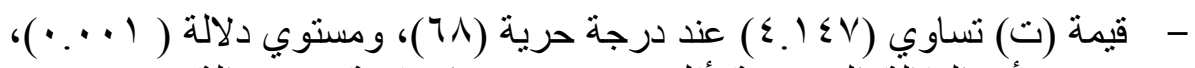

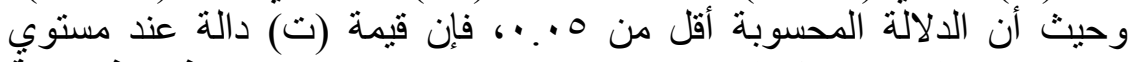

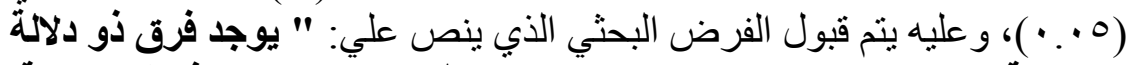

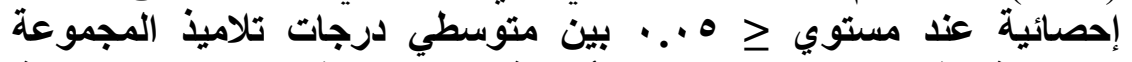
التجريبية الذين يدرسون باستخدام أنثطة

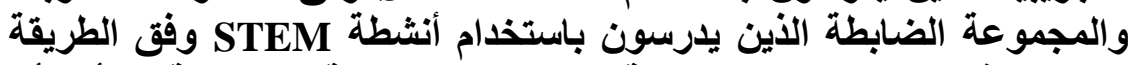

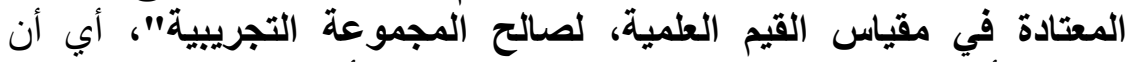

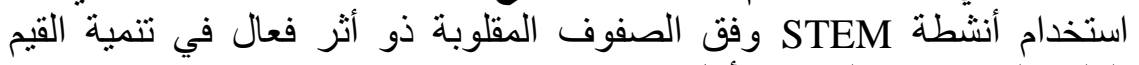
العلمية لدي تلاميذ الصف الأول الإعدادي.

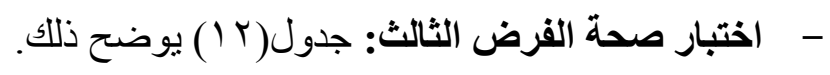

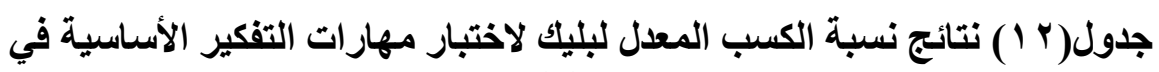

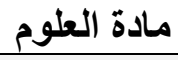

\begin{tabular}{|c|c|c|}
\hline نسبة الكسب المعدل لبليك & متوسط التطبيق البعدي & متوسط التطبيق القبلي \\
\hline $1 . K \mu$ & $\leqslant 7 . \wedge T$ & KA. ${ }^{\prime}$ \\
\hline
\end{tabular}

ويتضح من جدول(r Y )، أن متوسط درجات تلاميذ المجموعة التجريبية(الذين

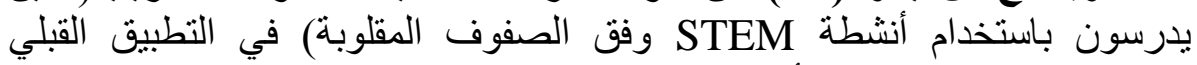

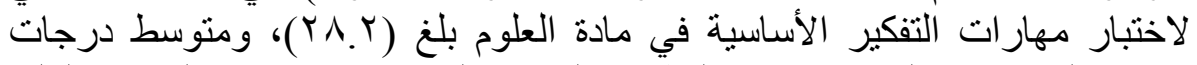

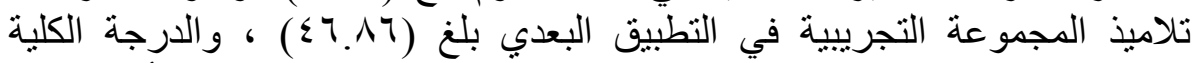

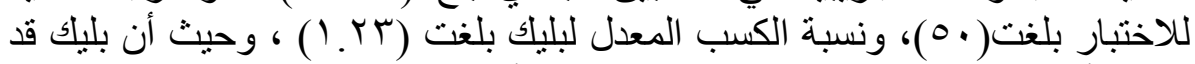

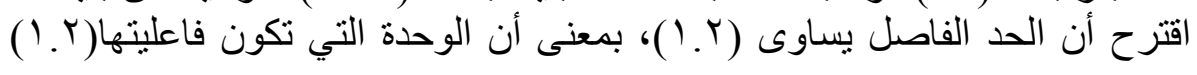


فأكثر ذات فاعلية، وبالتالي فإن الوحدة موضع التجريب ذات فاعلية في في تنمية

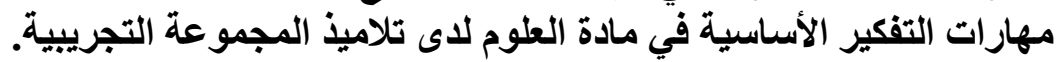

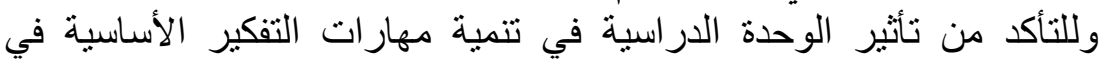

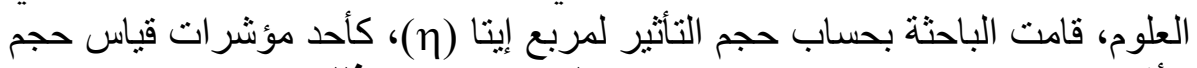
الأثر. (رشدي منصور،

جدول(r I ) الجدول المرجعي لتحديد مستويات حجم التأثير لمربع إيتا

\begin{tabular}{|c|c|c|c|}
\hline كبير & متوسط & ضعيف & مستوى حجم التأثير \\
\hline أكبر من \& 1 .•-1 & أكبر من 7 •. • _ 1 . • & من 1 ..•- •. & قيم مربع إيتا \\
\hline
\end{tabular}

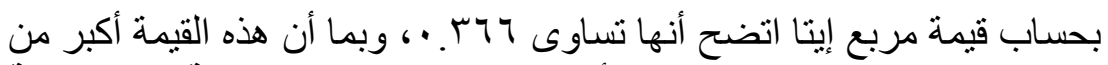

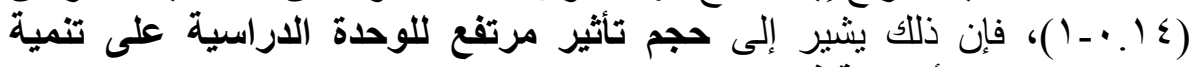
مهارات التفكير الأساسية في العلوم. لمئر

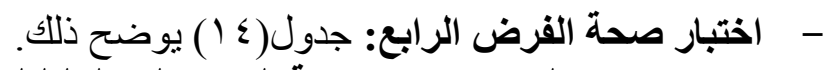

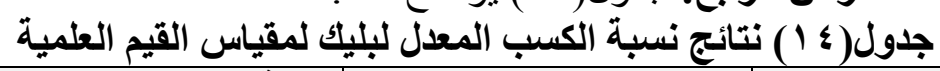

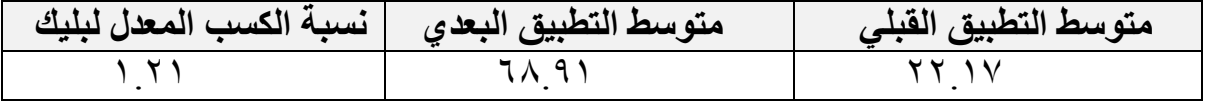

ويتضح من جدول(\& 1 )، أن متوسط درجات تلاميذ المجموعة التجريبية(الذين

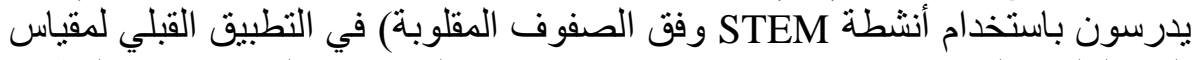

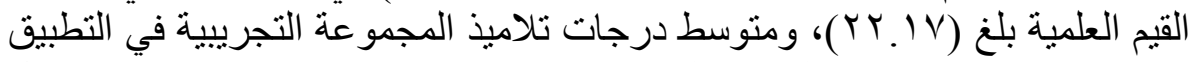

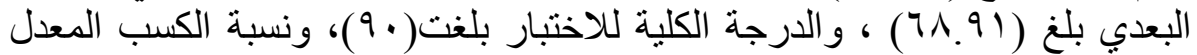

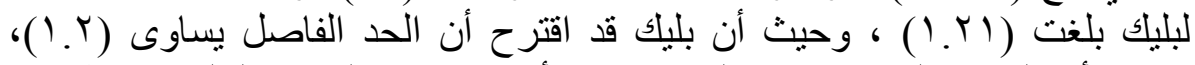

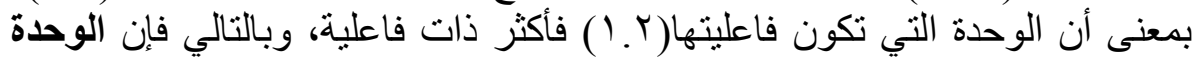

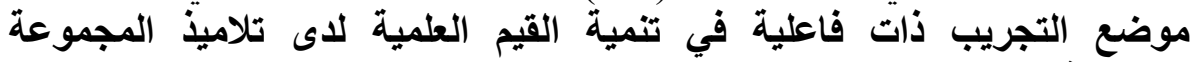
التجريبية.

وللتأكد من نأثير الوحدة الدراسية في تنمية القيم العلمية، قامت الباحثة بحساب

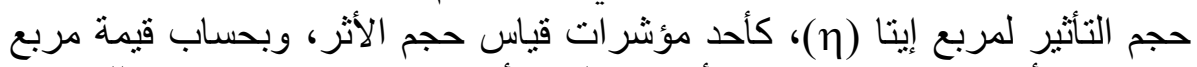

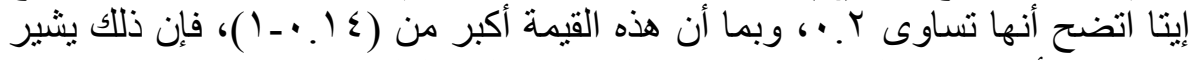
إلى حجم تأثثير مرتفع للوحدة الدار اسية على تثمية القيم العلمية. 
مناقشة النتائج وتفسير ها:

- باستعر اض نتائج جدول (9) يتضح أن هنالك فرق ذو دلالة إحصائية عند مستوي

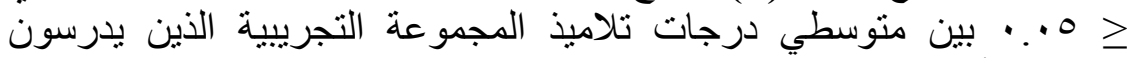

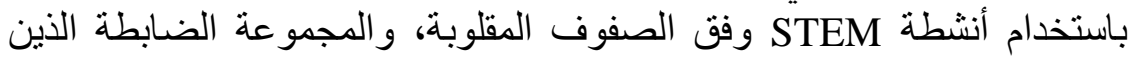
يدرسون باستخدام أنشطة STEM وفق الطريقة المعتادة في اختبار مهارات

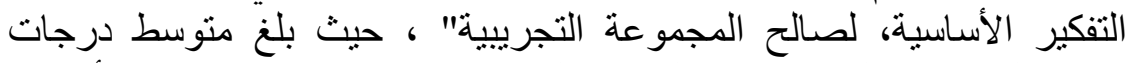

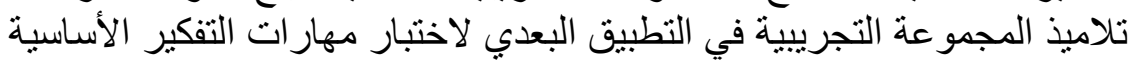

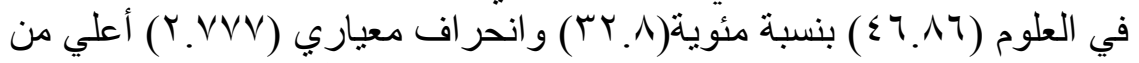

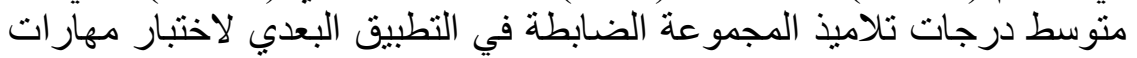

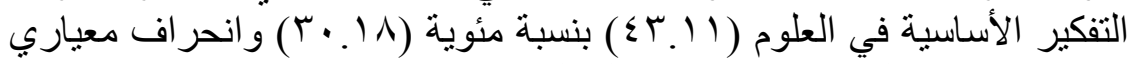

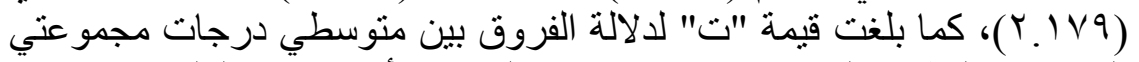

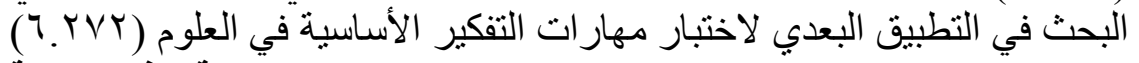

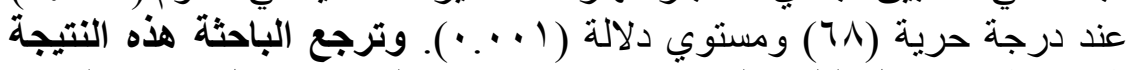

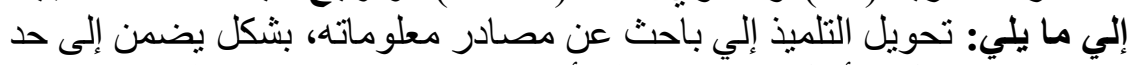

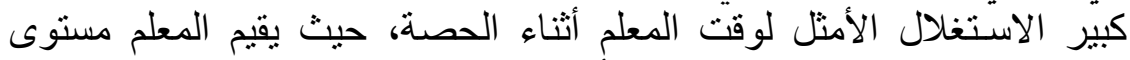

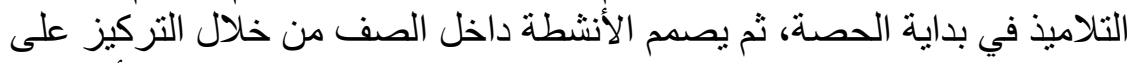

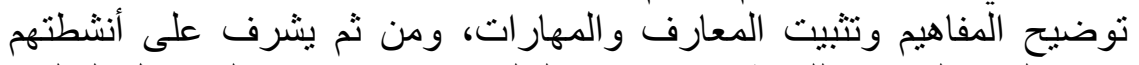

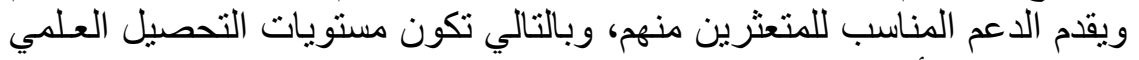

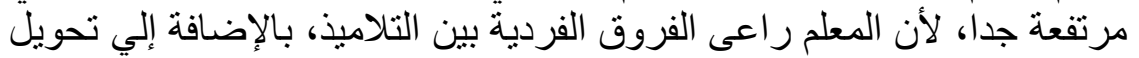

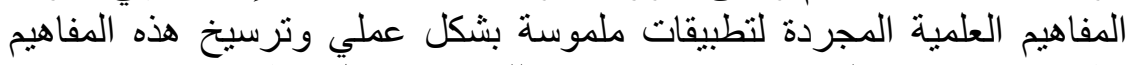

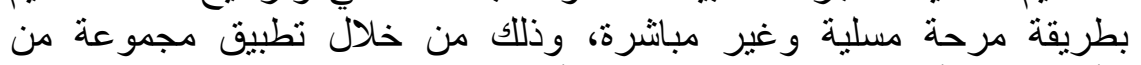

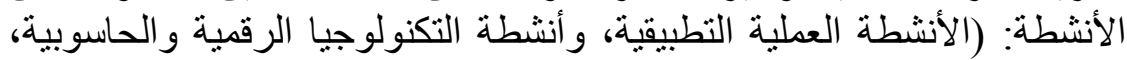

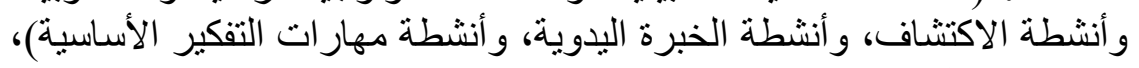

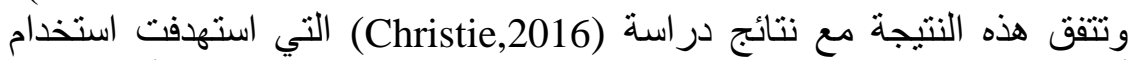

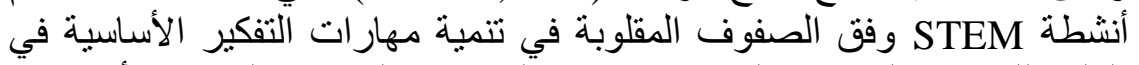
العلوم للتلاميذ بالمستوي السادس بو لاية كالليفورنيا بالو لايات التهات المتحدة الأمريكية،

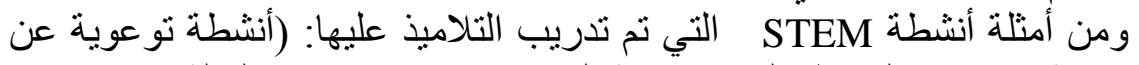
صحة الإنسان و الحفاظ عليها، برمجة الروبة الثربوت، وحدات قياس الكتلة و غير ها).

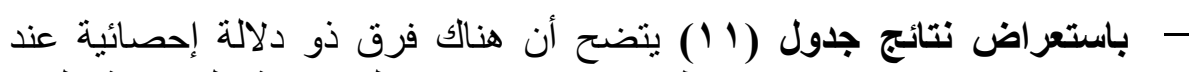

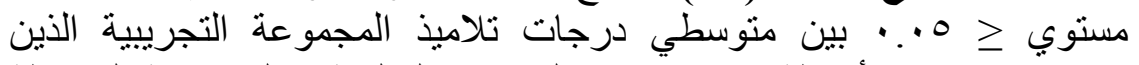

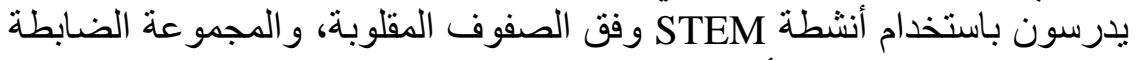

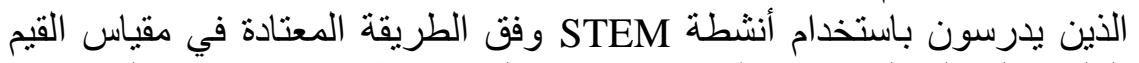

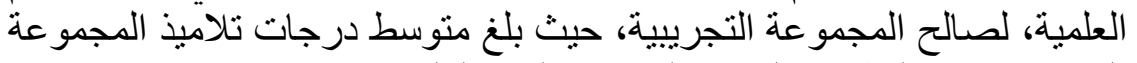

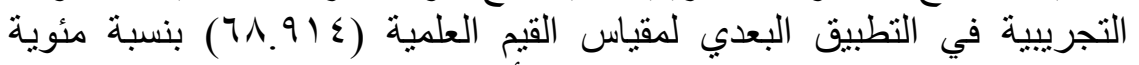

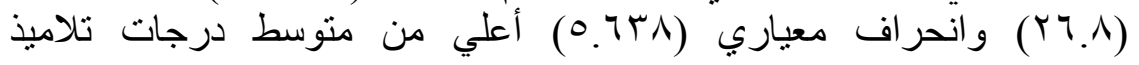




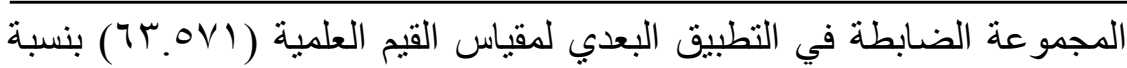

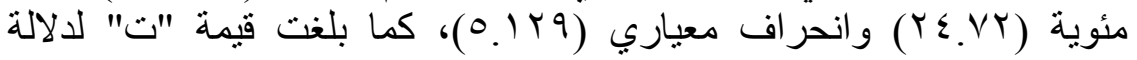

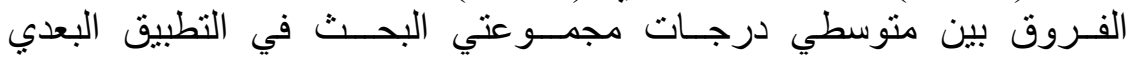

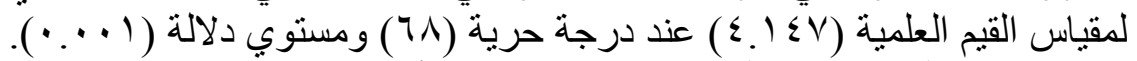
وترجع الباحثة هذه النتيجة إلي ما يلي: استخدام أنشطة

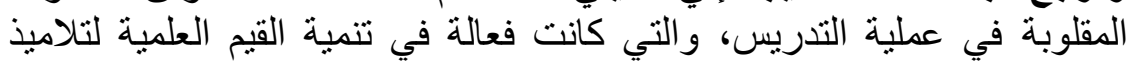

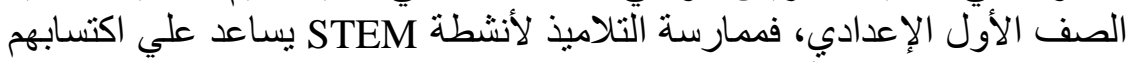

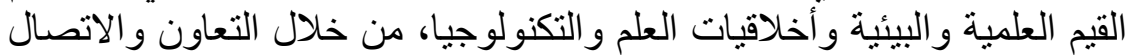

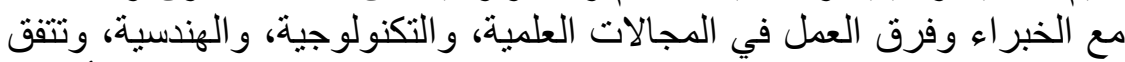

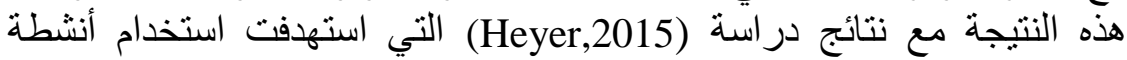

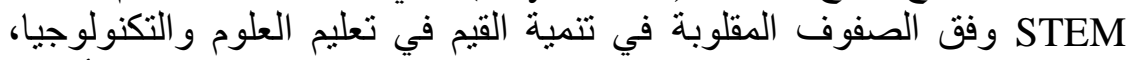

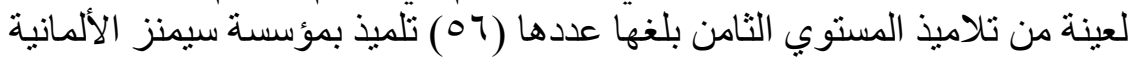
للعلوم و التكنولوجيا.

التوصيات: في ضوء النتائج التي توصلت إليها الدر اسة ومناقشتها، فإن الباحثة

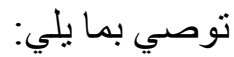

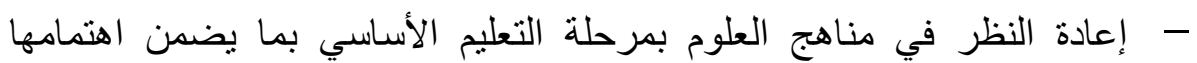

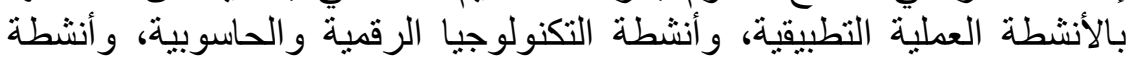
الاكتشاف، وأنشطة الخبرة اليدوية، و أنشطة مهار ات التفئة التفكير الأساسية.

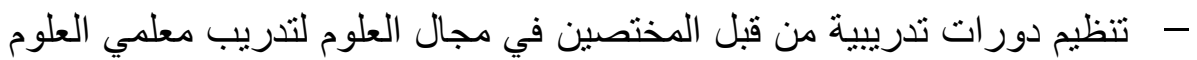

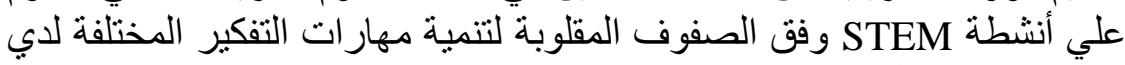
المتعلمين بمر احل التعليم المختلفة.

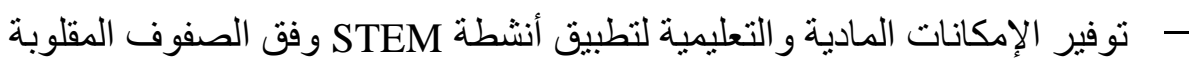
من حيث توفير الأدوات و المعادية والنطل لتنفيذ تلكئ الأنشطة.

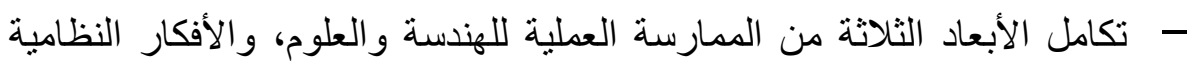

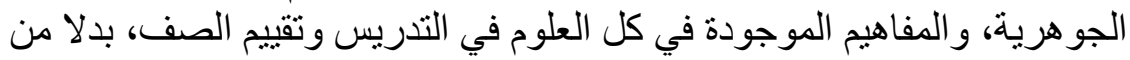
تدريسها منفصلة.

- توظيف أساليب وتقنيات تعليمية حديثة في التدريس للتقليل من جمود المفاهيم

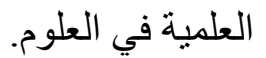

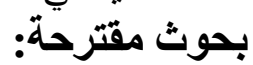

في ضوء النتائج التي توصلت إليها الدراسة ومناقتشتها، فإن الباحثة تقدم مجمو عةٌ من البحوث التي يمكن إجر اؤ ها مستقبلا منها:

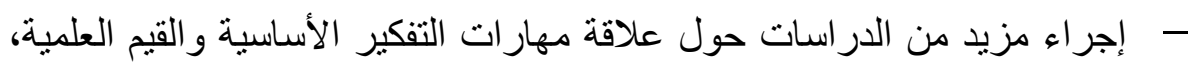

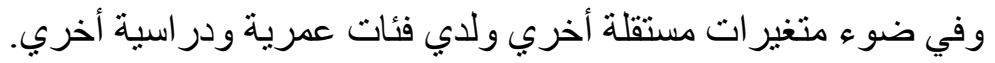




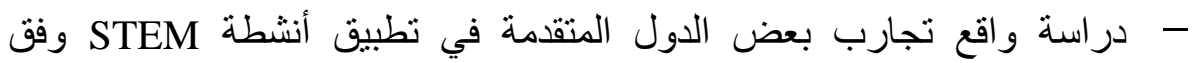
الصفوف المقلوبة في مادة العلوم بالمر احل التعليمية المختلفة. - - تضمين أنشطة STEM بمناهج العلوم الدر اسية بمر احل التعليم المختلفة. - - دراسة تجارب بعض الدول في التطوير المهني لمعلمي العلوم في المجالات العلمية و التقنية.

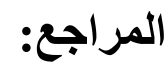

\section{أولا: المراجع العربية}

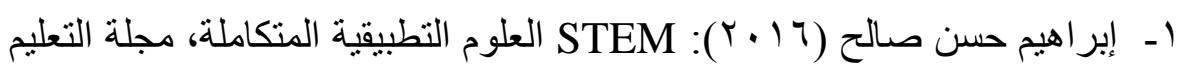

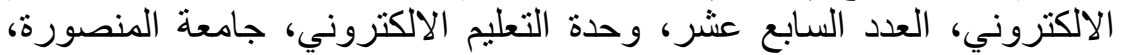

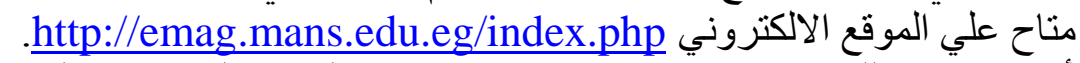

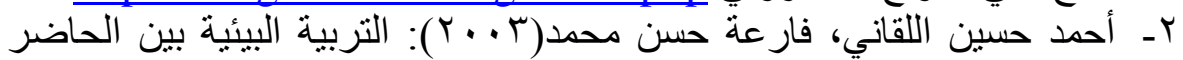

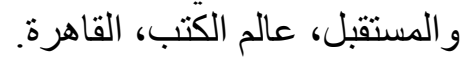

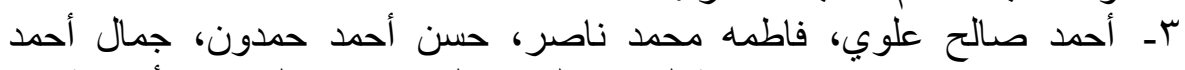

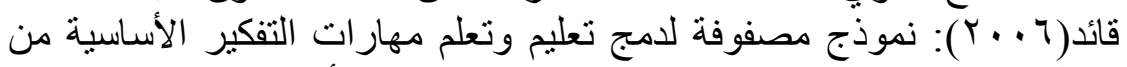

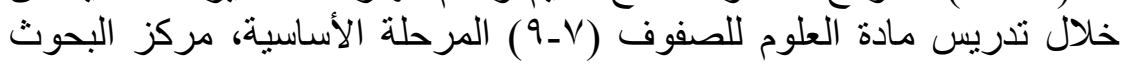

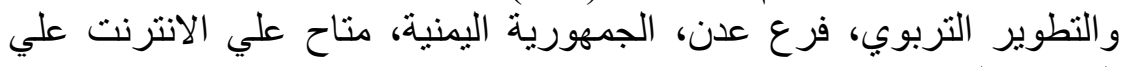

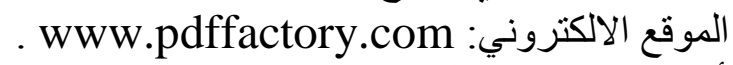

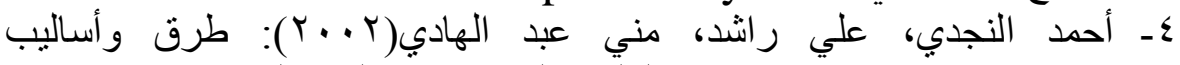

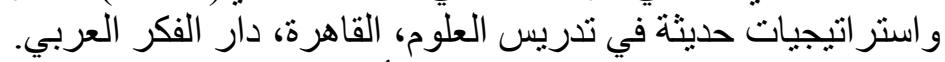

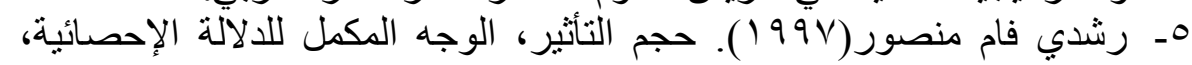

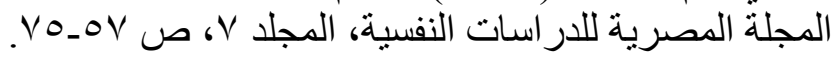

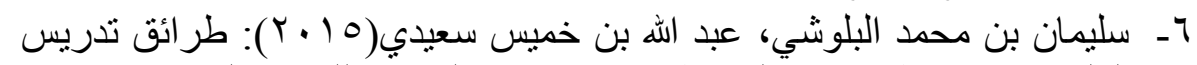

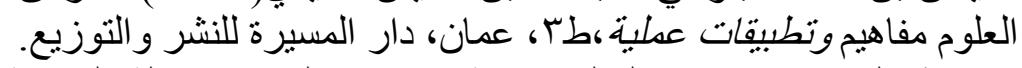

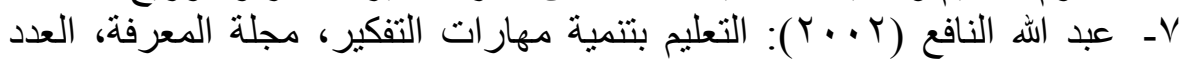

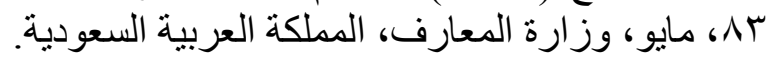

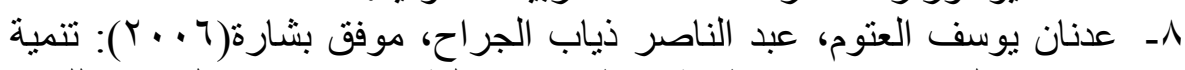

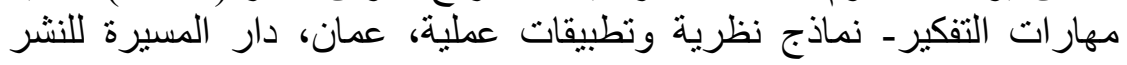
والتوزيع.

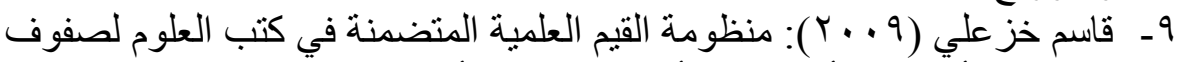

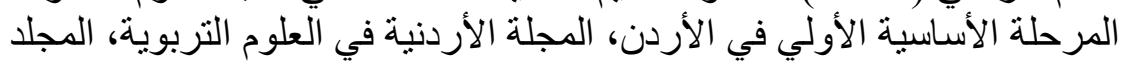

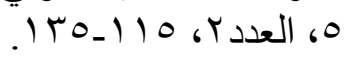




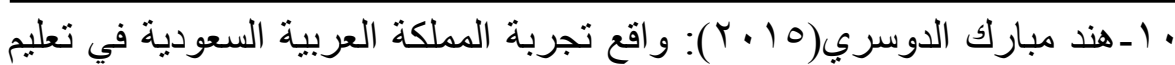
عTEM

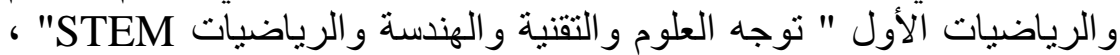

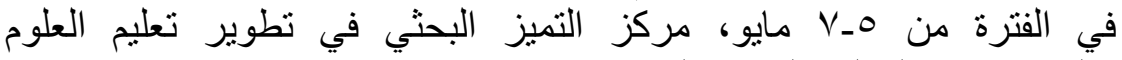
و أرياضيات، المملكة العربية السعودية.

\section{ثنانيا: المراجع الأجنبية}

11-Alswat,M.(2014).Effects Of Flipping The Classroom on Suburban Middle School Math Students, A Master 's Project Proposal Submitted in Partial Fulfillment of The Requirements for The Degree of Master of Science in Education Curriculum and Instruction, State University of New York at Fredonia, Fredonia, New York.

12-Barry,D.\&Kanematsu,H.(2006).Science Fair Competition Generates Excitement and Promotes Basic Thinking Skills in Japan, ERIC Digest No.656 214, Retrieved from http://www.eric.ed.gov.

13-Berrett,D.(2012).How Flipping The Classroom can improve The Traditional Lecture, Education Digest: Essential Readings Condensed for Quick Review, Vol 78,No.1,36.

14-Bormann,J.(2014).Affordances of Flipped Learning and Its Effects on Student Engagement and Achievement, Master Dissertation, University of Northern Iowa.

15-Candrasekaran,S.(2014).Developing Scientific Values, Thinking Skills and Creative Intelligence of Higher Secondary School Biology Students, International Journal of Humanities and Social Science Invention, Vol 31, Issue 6, 18. 
16-Christie,A.(2016).Enhancing STEM Learning in your Classroom, Bureau of Education \& Research, Retrieved from: https://www.ber.org/seminars/CourseInfo.cfm?.

17-Egan,K.(2012).Imagination in Teaching and Learning (Introduction), Retrieved from: https://www.sfu.ca/ egan/ITLintro.html.

18-Gaughan,J.(2014).The Flipped Classroom in World History, The History Teacher, Vol 47, NO.2.

19-Hall,W.\&Keynes,M.(2005).Types of Thinking ,This Publication Forms Part of an Open University, United Kingdom, Retrieved from :http://www.open.ac.uk.

20-Harlen,W.(2015).Working with Big Ideas of Science Education, Published by the Science Education Programme, The global network of science academies, Retrieved from : www.interacadmies.net.

21-Heyer,K.(2015). STEM and Values: Creating Values in Science and Technology Education, Retrieved from: https://www.siemens-stiftung.org/.

22-Karal,H\&Peksen,M.(2013).Using STEM Approach within Flipping The Classroom in Development Scientific imagination, Journal of Mathematics, Science \& Technology Educatio, Vol 5,NO.2,PP186-210.

23-Kessel,C.(2010). Dimensions of learning model for Marzano in the development of thinking Skills and Scientific Values, International Journal of Science Education.24,5,324-345. 
24-National Assessment of Educational Progress (NAEP) .(2010).Conceptual Understanding, Retrieved from http://nces.ed.gov/nationsreportcard.

25-National Center for Improving Science Education(NCISE).(2016).Developing Scientific Values, Retrieved from http://www.wested.org/project/nationalcenter.

26-Rule,A.(2015). The relationship between thinking Skills and Scientific Values, Dissertation Abstract International, $55, \mathrm{p} 3751$.

27-Talisayon,V.(2010).Development of Thinking Skills and Values in Physics Education, Retrieved from http://web.phys.ksu.edu/icpe.

28-The International Conference on STEM Education(2014).STEM Education and Our Planet Making Connections Across Contexts, University of British Columbia,14-16 July, Retrieved from: www.ubcconferences.com.

29-Tsupros,N.(2009).Science, Technology, Engineering, and Mathematics(STEM) Education What from? What Fuction?, Retrieved from: https://dornsife.usc.edu/assets/sites. 